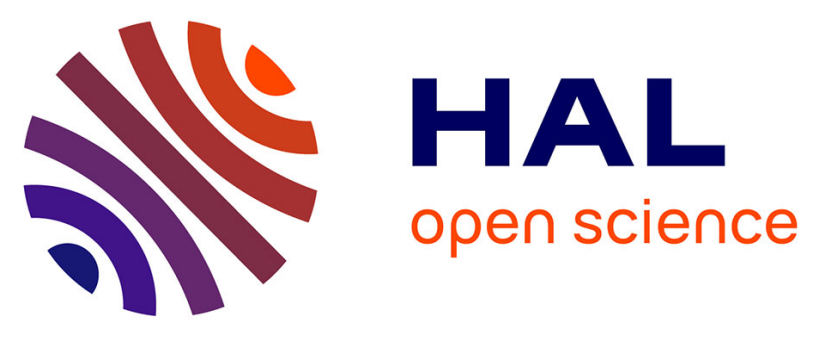

\title{
Tamoxifen-like metallocifens target the thioredoxin system determining mitochondrial impairment leading to apoptosis in Jurkat cells
}

Valeria Scalcon, Michèle Salmain, Alessandra Folda, Siden Top, Pascal Pigeon, Hui Zhi Shirley Lee, Gérard Jaouen, Alberto Bindoli, Anne Vessieres, Maria Pia Rigobello

\section{To cite this version:}

Valeria Scalcon, Michèle Salmain, Alessandra Folda, Siden Top, Pascal Pigeon, et al.. Tamoxifen-like metallocifens target the thioredoxin system determining mitochondrial impairment leading to apoptosis in Jurkat cells. Metallomics, 2017, 9 (7), pp.949-959. 10.1039/C7MT00121E . hal-01611386

\section{HAL Id: hal-01611386 \\ https://hal.sorbonne-universite.fr/hal-01611386}

Submitted on 8 May 2018

HAL is a multi-disciplinary open access archive for the deposit and dissemination of scientific research documents, whether they are published or not. The documents may come from teaching and research institutions in France or abroad, or from public or private research centers.
L'archive ouverte pluridisciplinaire HAL, est destinée au dépôt et à la diffusion de documents scientifiques de niveau recherche, publiés ou non, émanant des établissements d'enseignement et de recherche français ou étrangers, des laboratoires publics ou privés. 


\section{Tamoxifen-like metallocifens target the thioredoxin system determining mitochondrial impairment leading to apoptosis in Jurkat cells}

Valeria Scalcon, ${ }^{\mathrm{a}^{*}}$ Michèle Salmain, ${ }^{\mathrm{b}^{*}}$ Alessandra Folda, ${ }^{\mathrm{a}}$ Siden Top, ${ }^{\mathrm{b}}$ Pascal Pigeon, ${ }^{\text {bc }}$ Hui Zhi Shirley Lee, ${ }^{\text {bc }}$ Gérard Jaouen, ${ }^{\text {bc }}$ Alberto Bindoli, ${ }^{d}$ Anne Vessières $^{\mathrm{b}^{* *}}$ and Maria Pia Rigobello ${ }^{\mathrm{a}^{* *}}$

a) Dipartimento di Scienze Biomediche, Università di Padova, Via Ugo Bassi 58/b, 35131 Padova, Italy

b) Sorbonne Universités, UPMC Univ Paris 06, CNRS, Institut Parisien de Chimie Moléculaire (IPCM), F-75005 Paris, France

c) Chimie ParisTech, 11 rue Pierre et Marie Curie, F-75005 Paris, France

d) Istituto di Neuroscienze (CNR) Sezione di Padova, c/o Dipartimento di Scienze Biomediche, Via Ugo Bassi 58/b, 35131 Padova, Italy

*Valeria Scalcon and Michèle Salmain contributed equally to the work

** Anne Vessières and Maria Pia Rigobello: co-corresponding authors

Tamoxifen-like metallocifens (TLMs) of the group-8 metals (Fe, $\mathrm{Ru}$, and Os) show strong anti-proliferative activity on cancer cell lines resistant to apoptosis, owing to their unique redox properties. In contrast, the thioredoxin system, which is involved in cellular redox balance, is often overexpressed in cancer cells, especially in tumour types resistant to standard chemotherapies. Therefore, we investigated the effect of these three TLMs on the thioredoxin system and evaluated the input of the metallocene unit in comparison with structurally related organic tamoxifens. In vitro, all three TLMs became strong inhibitors of the cytosolic (TrxR1) and mitochondrial (TrxR2) isoforms of thioredoxin reductase after enzymatic oxidation with $\mathrm{HRP} / \mathrm{H}_{2} \mathrm{O}_{2}$ while none of the organic analogues was effective. In Jurkat cells, TLMs inhibited mainly TrxR2, resulting in the accumulation of oxidized thioredoxin 2 and cell redox imbalance. Overproduction of ROS resulted in a strong decrease in the mitochondrial membrane potential, translocation of cytochrome $c$ to the cytosol and 
activation of caspase 3 , thus leading to apoptosis. None of these events occurred with organic tamoxifens. The mitochondrial fraction of cells exposed to TLMs contained a high amount of the corresponding metal, as quantified by ICP-OES. The lipophilic and cationic character associated with the singular redox properties of the TLMs could explain why they alter the mitochondrial function. These results provide new insights into the mechanism of action of tamoxifen-like metallocifens, underlying their prodrug behaviour and the pivotal role played by the metallocenic entity in their cytotoxic activity associated with the induction of apoptosis.

\section{Significance to metallomics}

The biological effects of tamoxifen-like metallocifens (TLMs) of iron, ruthenium and osmium on Jurkat cells were compared to those of the corresponding organic tamoxifens. All three TLMs behaved as strong inhibitors of mitochondrial thioredoxin reductase both in vitro and in Jurkat cells, and induced mitochondrial membrane depolarization and eventually cell apoptosis. The organic molecules were inactive in this set of experiments, thus underlying the role of the metals. These effects are associated with the unique redox properties of the metallocene units and charge-driven accumulation of TLMs in mitochondria. Among the three compounds, the ferrocenyl TLM appeared to be the most active.

\section{Introduction}

Breast cancer remains the most common malignancy in women, and despite the efforts that have been expended on its early detection, half a million people died from this disease in 2012. ${ }^{1}$ Early breast cancer is now considered potentially curable and tamoxifen administration is the standard endocrine therapy of hormone receptor positive breast cancer. This is not the case for metastatic breast cancers, which are heterogeneous, often resistant to apoptosis and consequently difficult to cure. Thus, the search for new drugs with mechanisms of action different from those already in use is urgently needed. Some of us introduced some time ago the ferrocenyl analogues of OH-tamoxifen (OH-Tam[2], Chart 1), an active metabolite of tamoxifen. ${ }^{2,3}$ Not only did these compounds have an antioestrogenic effect on hormone-dependent breast cancer cells, but they also displayed high cytotoxicity on the triple negative breast cell line MDA-MB-231 $\left(\mathrm{IC}_{50}=0.5 \mu \mathrm{M}\right.$ for FcOH-Tam) ${ }^{3}$ as well as on a panel of cells resistant to apoptosis (glioma and melanoma). ${ }^{4,5}$ 


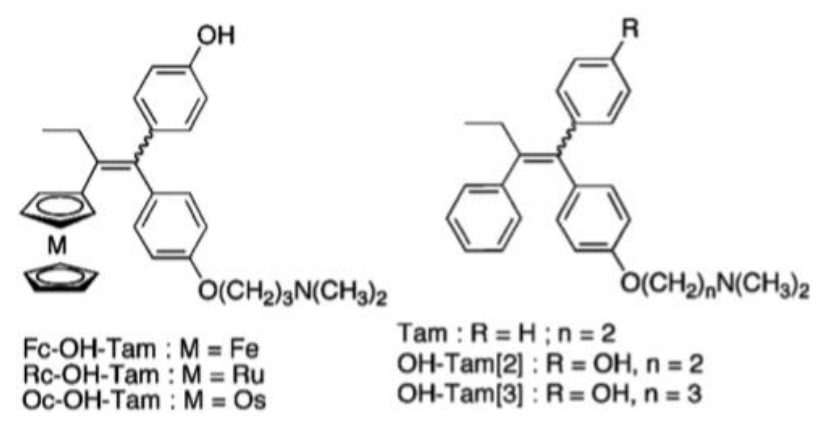

Chart 1 Formulae of the compounds under study.

In addition, Fc-OH-Tam significantly inhibited in vivo growth of MDA-MB-231 xenografted tumours in mice when formulated in lipid nanocapsules (LNCs). ${ }^{4}$ Regarding the mechanism of action of this complex, we found that Fc-OH-Tam induced strong senescence in MDA-MB-231 and low apoptosis. ${ }^{6}$ These remarkable properties have been linked to the presence of the [Fc-ene-phenol] motif that is selectively activated in cancer cells, therefore revealing their redox environment. ${ }^{7}$ As such, Fc-OH-Tam acts as a prodrug whose cytotoxicity is associated with its oxidation to a highly electrophilic quinone methide. $^{7}$ More recently we found that the quinone methide of Fc-OH-Tam was able to strongly inhibit the enzyme thioredoxin reductase (TrxR) in vitro. ${ }^{8}$ TrxR belongs to the thioredoxin system, which, together with the glutathione system, is responsible for thiol redox homeostasis. It is present as cytosolic (TrxR1) and mitochondrial (TrxR2) isoforms, displaying a selenocysteine residue at its C-terminal active site, which acts as a major target of electrophiles as well as many metal complexes. ${ }^{9-12}$ TrxR is often overexpressed in cancer cells and its inhibition may lead to cell apoptosis. ${ }^{13,14}$ Fc-OH-Tam inhibits TrxR in Jurkat cells, indicating that its conversion to quinone methide occurs in cellulo via endogenous oxidizing systems. Recent studies on the tamoxifen-like complex of osmium (Oc-OH-Tam, Chart 1) showed that in vitro inhibition of TrxR only occurred after its enzymatic oxidation by the HRP/ $\mathrm{H}_{2} \mathrm{O}_{2}$ mixture. Although less cytotoxic than Fc-OH-Tam on the MDA-MB-231 cell line $\left(\mathrm{IC}_{50}=2.7 \mu \mathrm{M}\right){ }^{15} \mathbf{O c}-\mathbf{O H}$-Tam proved to be an effective inhibitor of TrxR in Jurkat cells, inducing mitochondrial dysfunction and cell death. ${ }^{16}$

To gain better insight into the mechanism of action of tamoxifen-like metallocifens (TLMs) and to evaluate the role played by the metallocenic unit we report here the comparison of some biological effects of TLMs of iron, ruthenium and osmium with those of their organic tamoxifen analogues (Chart 1). Experiments included in vitro studies on purified cytosolic and mitochondrial isoforms of TrxR (TrxR1 and TrxR2) followed by studies on 
mitochondrial functionality in Jurkat cells. In particular, the redox state of mitochondrial Trx, ROS level and mitochondrial membrane potential (MMP) were measured. In addition, the intracellular distribution of metals was determined using ICP-OES measurements. Overall, only TLMs and not their organic analogues were able to initiate cell apoptosis via a mitochondria-mediated pathway.

\section{Experimental}

\section{Materials}

Stock solutions of the compounds $\left(1 \times 10^{-2} \mathrm{M}\right)$ were prepared in DMSO and were stable for at least two months if kept at $4{ }^{\circ} \mathrm{C}$. Horseradish peroxidase (HRP), yeast glutathione reductase, Tam, OH-Tam[2], iodoacetamide (IAM), iodoacetic acid (IAA), DTNB and metal standards were purchased from Sigma Aldrich (Saint Louis, MO, USA). BIAM, TMRM, DHR and MitoSOX were purchased from Invitrogen (Thermo Fisher Scientific, Waltham, MA, USA). Primary antibodies were utilized: Trx2 monoclonal antibody (H75) and caspase-3 polyclonal antibody clone H-277 (Santa Cruz Biotechnology, Santa Cruz, CA, USA); cytochrome $c$ clone 7H8.C12 (BioSource International, Inc., Camarillo, CA, USA); anti-cytochrome $c$ oxidase subunit 4 monoclonal antibody 1D6 (Thermo Fisher Scientific, Waltham, MA, USA).

\section{Enzymatic oxidation of the compounds by the $\mathrm{HRP} / \mathrm{H}_{2} \mathrm{O}_{2}$ mixture}

Enzymatic oxidation of the compounds $(25-50 \mu \mathrm{M})$ by HRP $(46 \mathrm{nM})$ and $\mathrm{H}_{2} \mathrm{O}_{2}(200 \mu \mathrm{M})$ was performed at $\mathrm{pH} 8.1$ in buffer (0.2 M Tris-HCl, $1 \mathrm{mM}$ EDTA) containing 10\% DMSO. $\mathrm{HRP}$ (40 $\mu \mathrm{L}$ of $1.14 \mu \mathrm{M}$ solution) and $\mathrm{H}_{2} \mathrm{O}_{2}(20 \mu \mathrm{L}$ of $10 \mathrm{mM}$ solution) were pre-incubated for $5 \mathrm{~min}$ and then added to the solution of the compounds $(940 \mu \mathrm{L})$. The solution was immediately transferred to a cuvette and the UV-Visible spectrum was recorded between 250 and $600 \mathrm{~nm}$ every $30 \mathrm{~s}$ on a Cary 50 spectrometer (Varian, Palo Alto, CA, USA). Rate constants $k_{\mathrm{obs}}$ were calculated using Kaleidagraph software by fitting $\mathrm{OD}_{324 \mathrm{~nm}}$ (Oc-OHTam), $\mathrm{OD}_{413 \mathrm{~nm}}$ (Fc-OH-Tam), $\mathrm{OD}_{418 \mathrm{~nm}}$ (Rc-OH-Tam) and $\mathrm{OD}_{279 \mathrm{~nm}}$ (OH-Tam[3]) versus time data according to the first order law equation: $\mathrm{OD}=C_{0}+C_{1} \times \exp \left(-k_{\mathrm{obs}} \mathrm{x} t\right)$. 


\section{Enzymatic activity estimation of isolated TrxR1 and TrxR2}

Highly purified cytosolic (TrxR1) and mitochondrial (TrxR2) thioredoxin reductases were prepared from rat liver according to Luthman and Holmgren ${ }^{17}$ and Rigobello and Bindoli, ${ }^{18}$ respectively. The protein content of the purified enzyme preparations was measured according to Lowry et al. ${ }^{19}$ Thioredoxin reductase activity was determined by estimating the DTNB- reducing properties of the enzymes in the presence of NADPH. Aliquots of highly purified TrxR1 or TrxR2 in $0.2 \mathrm{M}$ Tris- $\mathrm{HCl}$ buffer $(\mathrm{pH} 8.1), 1 \mathrm{mM}$ EDTA and $0.25 \mathrm{mM}$ NADPH were pre-incubated for 5 min with various compounds. Afterwards, the reaction was initiated with $1 \mathrm{mM}$ DTNB and monitored spectrophotometrically at $412 \mathrm{~nm}$ for about 10 min. For the formation of oxidized metallocifen derivatives, freshly prepared compounds at increasing concentrations were incubated for $15 \mathrm{~min}$ in $0.2 \mathrm{M}$ Tris- $\mathrm{HCl}$ buffer $(\mathrm{pH} 8.1)$ containing $1 \mathrm{mM}$ EDTA, $0.1 \mathrm{mM} \mathrm{H}_{2} \mathrm{O}_{2}$ and $22 \mathrm{nM}$ HRP. Then, TrxR aliquots and $0.25 \mathrm{mM}$ NADPH were added and incubated for 5 min. Finally, the reaction was initiated with $1 \mathrm{mM}$ DTNB and monitored spectrophotometrically at $412 \mathrm{~nm}$ for about $10 \mathrm{~min}$.

\section{BIAM assay}

First, TLMs and organic tamoxifen were treated with the mixture of $22 \mathrm{nM} \mathrm{HRP} / 0.1 \mathrm{mM}$ $\mathrm{H}_{2} \mathrm{O}_{2}$ for $15 \mathrm{~min}$ as reported in the previous paragraph. Then, $1 \mu \mathrm{M}$ TrxR pre-reduced in the presence of $60 \mu \mathrm{M}$ NADPH was incubated with $2 \mu \mathrm{M}$ of the obtained derivatives for 30 min at room temperature, in $50 \mathrm{mM}$ Tris- $\mathrm{HCl}$ buffer $(\mathrm{pH}$ 7.4) containing $200 \mu \mathrm{M}$ NADPH and $1 \mathrm{mM}$ EDTA. After incubation, $8 \mu \mathrm{L}$ of the reaction mixture was added to $8 \mu \mathrm{L}$ of 100 $\mu \mathrm{M}$ biotinylated iodoacetamide (BIAM) in $0.1 \mathrm{M}$ Tris- $\mathrm{HCl}$ at $\mathrm{pH} 8.5$ or in $0.1 \mathrm{M}$ HepesTris $\mathrm{pH} 6.0 .^{20}$ The samples were incubated at room temperature for an additional $30 \mathrm{~min}$ to allow BIAM alkylation of free $-\mathrm{SH} / \mathrm{SeH}$ groups of the enzyme. Then, BIAM-modified enzyme was subjected to sodium dodecyl sulphate-polyacrylamide gel electrophoresis (SDSPAGE) on a $10 \%$ gel, and transferred to a nitrocellulose membrane. BIAM labelled enzyme was detected with horseradish peroxidase-conjugated streptavidin and enhanced chemiluminescence detection.

\section{Determination of total thioredoxin reductase activity in Jurkat cell lysates}

The human leukemic lymphoblastoid Jurkat cells were cultured in RPMI 1640 medium 
supplemented with $2 \mathrm{mM}$ L-glutamine, 10\% FBS and 1\% penicillin/streptomycin (Invitrogen) at $37{ }^{\circ} \mathrm{C}$ in a humidified atmosphere of 95\% air and $5 \% \mathrm{CO}_{2}$. Cells $\left(2 \times 10^{6}\right)$ were incubated with $15 \mu \mathrm{M}$ compounds for $18 \mathrm{~h}$, then harvested and washed with PBS. Each sample was lysed with a modified RIPA buffer: $150 \mathrm{mM} \mathrm{NaCl}, 50 \mathrm{mM}$ Tris- $\mathrm{HCl}, 1 \mathrm{mM}$ EDTA, $1 \%$ Triton X-100, 0.1\% SDS, 0.5\% DOC, $1 \mathrm{mM} \mathrm{NaF}$ and an antiprotease cocktail ("Complete" Roche, Mannheim, Germany) containing $0.1 \mathrm{mM}$ PMSF. After $40 \mathrm{~min}$ at 4 ${ }^{\circ} \mathrm{C}$, the lysates were centrifuged at $12000 \mathrm{~g}$ for $6 \mathrm{~min}$. The supernatants were tested for total TrxR activity. Therefore, aliquots of lysates (12 $\mu \mathrm{g}$ proteins) were incubated for $40 \mathrm{~min}$ in a final volume of $50 \mu \mathrm{L}$ in $100 \mathrm{mM}$ Hepes-Tris buffer $(\mathrm{pH} \mathrm{7.6)}$ in the presence of $15 \mathrm{mM}$ EDTA, $1.5 \mathrm{mM}$ NADPH, $0.20 \mathrm{mM}$ insulin, and $100 \mu \mathrm{M}$ Trx from E. coli. The reaction was stopped by adding $0.2 \mathrm{~mL}$ of $1 \mathrm{mM}$ DTNB in $0.2 \mathrm{M}$ Tris- $\mathrm{HCl}$ buffer ( $\mathrm{pH} 8.1$ ) containing $1 \mathrm{mM}$ EDTA and 7.2 M guanidine, and the samples' O.D. was estimated at 412 $\mathrm{nm}^{21}$ on a plate reader (Tecan Infinite ${ }^{\circledR}$ M200 PRO, Männedorf, $\mathrm{CH}$ ).

\section{Preparation of cytosol and mitochondria enriched fractions and evaluation of thioredoxin reductase activity}

To obtain cytosolic and mitochondrial fractions, Jurkat cells $\left(3 \times 10^{7}\right)$ were grown in $75 \mathrm{~cm}^{2}$ flasks and then treated with various compounds $(30 \mu \mathrm{M})$ for $18 \mathrm{~h}$. After incubation, the cells were processed to obtain mitochondria and cytosol enriched fractions essentially following the protocol of Clayton and Shadel. ${ }^{22}$ Briefly, the cells were collected, washed with PBS and subjected to hypo-osmotic treatment with $2 \mathrm{~mL}$ of $10 \mathrm{mM}$ $\mathrm{NaCl}, 1.5 \mathrm{mM} \mathrm{MgCl} 2$ and $10 \mathrm{mM}$ Tris- $\mathrm{HCl}(\mathrm{pH} \mathrm{7.5)}$ for $5 \mathrm{~min}$ and gently homogenized using a Dounce tissue grinder. After this treatment, $1.4 \mathrm{~mL}$ of $525 \mathrm{mM}$ mannitol, 175 $\mathrm{mM}$ sucrose, $12.5 \mathrm{mM}$ Tris- $\mathrm{HCl}(\mathrm{pH} \mathrm{7.5)}$ and $2.5 \mathrm{mM}$ EDTA (pH 7.5) were rapidly added. Then, the homogenate was diluted to a final volume of $5 \mathrm{~mL}$ with $210 \mathrm{mM}$ mannitol, $70 \mathrm{mM}$ sucrose, $5 \mathrm{mM}$ Tris- $\mathrm{HCl}(\mathrm{pH}$ 7.5) buffer, and $1 \mathrm{mM}$ EDTA (pH 7.5) and subjected to differential centrifugation. The first step was carried out at $1300 \mathrm{~g}$ for $5 \mathrm{~min}$ at 4 ${ }^{\circ} \mathrm{C}$ to discard nuclei and non-disrupted cells. The mitochondrial fraction was pulled down from the supernatant at $15800 \mathrm{~g}$ for $15 \mathrm{~min}$ at $4{ }^{\circ} \mathrm{C}$ and washed twice. The crude soluble supernatant obtained from the mitochondrial isolation step was further centrifuged at $105000 \mathrm{~g}$ for $15 \mathrm{~min}$ to obtain the cytosolic fraction. Afterwards, mitochondrial samples were lysed using a modified RIPA buffer, as reported in the previous paragraph, and subjected to protein 
determination with the Lowry assay. ${ }^{19}$ In addition, the presence of cytochrome oxidase as a mitochondrial marker was assessed by Western blot analysis using an anti-cytochrome $c$ oxidase subunit 4 monoclonal antibody 1D6. Both cytosolic and mitochondrial fractions (50 $\mu \mathrm{g}$ of proteins) were then tested for thioredoxin reductase activity in a buffer containing 0.2 M NaKPi, 5 mM EDTA (pH 7.4) and 20 mM DTNB. After 2 min, $0.25 \mathrm{mM}$ NADPH was added and the reaction was followed at $412 \mathrm{~nm}$ at $25{ }^{\circ} \mathrm{C}$ using a Lambda 2 spectrophotometer (PerkinElmer, Waltham, MA, USA).

\section{Redox Western blot analysis of Trx2}

The redox state of Trx was detected using a modified Western blot analysis. ${ }^{23,24}$ Briefly, after treatment with the compounds $(15 \mu \mathrm{M})$ for $18 \mathrm{~h}$, Jurkat cells $\left(2 \times 10^{6}\right)$ were washed with PBS and lysed in $100 \mu \mathrm{L}$ of urea lysis buffer (100 mM Tris-HCl, pH 8.3, containing $1 \mathrm{mM}$ EDTA, $8 \mathrm{M}$ urea, and $10 \mathrm{mM}$ IAM) in order to alkylate free thiols. Incubation was carried out at $37^{\circ} \mathrm{C}$ for $20 \mathrm{~min}$. Then, the cell lysates were spun down and precipitated by ice-cold acetone-1 $\mathrm{M} \mathrm{HCl}(98: 2)$. The pellets were washed twice with ice-cold acetone-1 M HCl- $\mathrm{H}_{2} \mathrm{O}$ (98:2 : 10), re-suspended in $60 \mu \mathrm{L}$ of urea lysis buffer including $3.5 \mathrm{mM}$ DTT, and incubated for $30 \mathrm{~min}$ at $37{ }^{\circ} \mathrm{C}$ to reduce the disulfide bonds. Afterwards, $3 \mu \mathrm{L}$ of $600 \mathrm{mM}$ IAM (final concentration $30 \mathrm{mM}$ ) were added to the samples, followed by incubation for $30 \mathrm{~min}$ at $37{ }^{\circ} \mathrm{C}$. The protein concentration was determined using the Lowry assay. ${ }^{19}$ The proteins were separated by urea-PAGE (7\% acrylamide/bis(acrylamide) in $7 \mathrm{M}$ urea) and blotted on a nitrocellulose membrane using a Trans-Blot ${ }^{\circledR}$ Turbot ${ }^{\mathrm{TM}}$ System (Bio-Rad Laboratories, Hercules, CA, USA). The membranes were probed with the primary antibody for Trx2 (H75).

\section{Flow cytometric analysis of the mitochondrial membrane potential and superoxide production in Jurkat cells}

The drug-influenced cell mitochondrial membrane potential was analyzed by flow cytometry with the fluorescent probe tetramethyl rhodamine methyl ester (TMRM). Jurkat cells ( $2 \mathrm{x}$ $\left.10^{6}\right)$ were treated for $18 \mathrm{~h}$ with the compounds $(15 \mu \mathrm{M})$ and then harvested and resuspended in PBS/10 mM glucose/25 nM TMRM (final concentration) for $15 \mathrm{~min}$ at $37^{\circ} \mathrm{C}$ 
in the dark. Induced changes of the membrane potential were estimated with a FACSCanto $^{\text {TM }}$ II flow cytometer (Becton-Dickinson, CA, USA) using an argon laser at 585 $\mathrm{nm}$. Cells cultured and treated under the same conditions described above were also probed for mitochondrial superoxide production utilizing the fluorescent probe MitoSOX ${ }^{\mathrm{TM}}$ Red. After treatment with the complexes, Jurkat cells $\left(5 \times 10^{5}\right)$ were incubated with $1 \mu \mathrm{M}$ MitoSOX $^{\mathrm{TM}}$ in PBS/10 $\mathrm{mM}$ glucose for $25 \mathrm{~min}$ in the dark, then diluted $(1: 4)$ and analyzed on a FACSCanto ${ }^{\mathrm{TM}}$ using an argon laser at $585 \mathrm{~nm}$.

\section{Determination of short-term cellular ROS production in Jurkat cells}

Jurkat cells $\left(4 \times 10^{5}\right.$ per well) were seeded in a 96 well plate in PBS/10 mM glucose and then incubated for $1 \mathrm{~h}$ with $15 \mu \mathrm{M}$ dihydrorhodamine 123 (DHR) at $37{ }^{\circ} \mathrm{C}, 5 \% \mathrm{CO}_{2}$. Afterwards, the medium was removed and to each well $100 \mu \mathrm{M}$ PBS/10 mM glucose supplemented with $10 \mu \mathrm{M}$ TLMs or organic tamoxifen derivatives was added. Finally, ROS production was estimated by monitoring the fluorescence increase of the probe $(\lambda \mathrm{Ex}=500$ $\mathrm{nm}, \lambda \mathrm{Em}=536 \mathrm{~nm}$ ), using a Tecan Infinite ${ }^{\circledR}$ M200 PRO plate reader.

\section{Estimation of cytochrome $c$ release and caspase-3 activation}

Cytochrome $c$ release and caspase-3 activation were detected using the Western blot technique. After $18 \mathrm{~h}$ of incubation in the presence of $15 \mu \mathrm{M}$ of the compounds, Jurkat cells $\left(2 \times 10^{6}\right)$ were harvested, washed with PBS, and treated with a hypotonic lysis buffer (20 mM Hepes-Tris buffer (pH 7.5), $10 \mathrm{mM} \mathrm{KCl,} 1.5 \mathrm{mM} \mathrm{MgCl} 2,1 \mathrm{mM}$ EDTA and $1 \mathrm{mM}$ EGTA) added with an antiprotease cocktail (Complete, Roche, Mannheim, DE) for 15 min. Then, the suspension was centrifuged at $12500 \mathrm{~g}$ for $10 \mathrm{~min}$ at $4{ }^{\circ} \mathrm{C}$. The supernatant added with $0.5 \mathrm{mM}$ EGTA and $2.5 \mathrm{mM}$ PMSF was centrifuged for $30 \mathrm{~min}$ at $100000 \mathrm{~g}$ at 4 ${ }^{\circ} \mathrm{C}$ to obtain the cytosolic fraction. The pellet obtained from the first centrifugation was lysed in the previously reported modified RIPA buffer. Aliquots of $10 \mu \mathrm{g}$ protein of the supernatants or of the pellets were subjected to SDS-PAGE (15\%) followed by Western blot using a cytochrome $c$ monoclonal antibody clone 7H8.C12 and a caspase-3 polyclonal antibody clone H-277. A peroxidase-conjugated secondary antibody and 
chemiluminescence were used to detect the immunoreactive bands.

\section{Metal quantification in Jurkat cell compartments by ICP-OES}

Jurkat cells ( $3 \times 10^{7}$ cells) incubated for $24 \mathrm{~h}$ in the presence of the compounds $(30 \mu \mathrm{M})$ were subjected to cell fractionation, as reported in a previous paragraph. For the ICP-OES experiments, mitochondria and crude nuclei fractions were dissolved in $0.54 \mathrm{~mL} \mathrm{HCl}$ (37\%, Fluka for trace analysis) and digested at $60{ }^{\circ} \mathrm{C}$ in an ultrasound bath for $1 \mathrm{~h}$. Then, the samples' volume was brought to $10 \mathrm{~mL}$ by the addition of water $([\mathrm{HCl}]$ in the sample $=$ $2 \%$ ). The cytosol samples were adjusted to $2 \% \mathrm{HCl}$ by the addition of appropriate volumes of $37 \% \mathrm{HCl}$ and water (final volume $=10 \mathrm{~mL}$ ). All the solutions were filtered on a $0.45 \mu \mathrm{m}$ syringe filter. Quantification of iron, ruthenium and osmium was performed at 238.204, 267.876 and $225.585 \mathrm{~nm}$, respectively, using an Agilent 5100 instrument (Santa Clara, CA, USA). Metal standards (Fe, Ru and Os) were prepared from 1000 ppm stock solutions. The concentrations used for calibration were in all cases $0,7.8,15.6,31.2,62.5$, 125, 250 and $500 \mathrm{ppb}$. Measurements were done in triplicate in two or three sets of independent experiments. $\mathrm{HCl}$ was used instead of $\mathrm{HNO}_{3}$ as the latter leads to the formation of the highly toxic and volatile $\mathrm{OsO}_{4}$. The ICP-OES experiments were performed on the ALIPP6 platform at the University Pierre et Marie Curie.

\section{Statistical analysis}

All the experimental data reported, if not indicated, are the mean with their respective SD of at least 4 experiments. The statistical analyses of variance (ANOVA) were performed using the Tukey test with INSTAT 3.3 (GraphPad) software.

\section{Results}

\section{Synthesis}

The TLMs of the group-8 metals Fc-OH-Tam, Rc-OH-Tam and Oc-OH-Tam (Chart 1) 
used in this study were prepared by following the previously reported protocols and are stable for months in the solid state. ${ }^{3,15,25}$ The TLMs were obtained as a mixture of $Z$ and $E$ stereomers. We previously found that these stereomers rapidly isomerize in protic medium. Thus, the experiments reported herein were performed with mixtures of $(Z+E)$ isomers of the 3 complexes. The biochemical behaviour of the TLMs was systematically compared to that of 3 analogous organic tamoxifens, namely Tam, its active metabolite OH-Tam[2], and OH-Tam[3], the organic analogue including the same dimethylamino-terminated side chain as in the three TLMs, which was prepared according to the literature. ${ }^{26}$

\section{Identification of the products of enzymatic oxidation by the $\mathrm{HRP} / \mathrm{H}_{2} \mathrm{O}_{2}$ mixture}

Enzymatic oxidation of the TLMs and their organic counterparts by the $\mathrm{HRP} / \mathrm{H}_{2} \mathrm{O}_{2}$ mixture was monitored by UV-visible spectrometry. For Fc-OH-Tam, the progressive appearance of an intense band at $402 \mathrm{~nm}$ was observed, which was readily assigned to quinone methide by comparison with the authentic product obtained by chemical oxidation with $\operatorname{Ag}_{2} \mathrm{O}$ (Fig. S1-A, ESI $\dagger$ ). ${ }^{7,27}$ This conversion corresponds to a 2-electron, 2-proton abstraction pathway. The same behaviour was found for Rc-OH-Tam for which a band at $418 \mathrm{~nm}$ was observed upon oxidation with $\mathrm{HRP} / \mathrm{H}_{2} \mathrm{O}_{2}$ (Fig. S1-B, ESI $\dagger$ ). In contrast, enzymatic oxidation of $\mathbf{O H}-$ Tam[3] led to the rapid disappearance of its characteristic band at $279 \mathrm{~nm}$ but no new peak appeared on the spectra (Fig. S1-C, ESI†). Thus, treatment of OH-Tam[3] by $\mathrm{HRP} / \mathrm{H}_{2} \mathrm{O}_{2}$ did not afford quinone methide, which is characterized by an intense band at around 400 nm. ${ }^{28}$ Previous literature data demonstrate that HRP oxidation of OH-Tam[2] rather affords unstable radical species that tend to polymerize. ${ }^{29} \mathrm{We}$ previously found that enzymatic oxidation of Oc-OH-Tam did not afford quinone methide as did chemical oxidation with $\mathrm{Ag}_{2} \mathrm{O}$ but rather led to a quinone methide carbocation characterized by a band at $331 \mathrm{~nm}$ resulting from a two-electron, 1-proton abstraction pathway. ${ }^{16}$ This unusual behaviour was assumed to originate from the high stability of carbenium ions derived from osmocene derivatives. $^{30,31}$ Table 1 summarizes the oxidation pathway of the compounds under study and the rate constants of oxidation upon treatment with $\mathrm{HRP} / \mathrm{H}_{2} \mathrm{O}_{2}$. As it appears, oxidation of all the compounds proceeded swiftly, with a slightly faster rate observed for ferrocifen than for ruthenocifen and osmocifen.

Table 1 Summary of the enzymatic oxidation experiments 


\begin{tabular}{|c|c|c|c|c|}
\hline Compound & Oxidation pathway & $\lambda \max (\mathrm{nm})$ & $\begin{array}{c}\text { Nature of } \\
\text { oxidation } \\
\text { product }\end{array}$ & $\begin{array}{l}\text { Rate constant of } \\
\text { oxidation }\left(\mathrm{min}^{-1}\right)\end{array}$ \\
\hline Fc-OH-Tam & $-2 \mathrm{e}^{-} /-2 \mathrm{H}^{\mathrm{a}}$ & 402 & QM & $0.521 \pm 0.022^{\mathrm{d}}$ \\
\hline Rc-OH-Tam & $-2 \mathrm{e}^{-/}-2 \mathrm{H}$ & 418 & QM & $0.319 \pm 0.008^{\mathrm{d}}$ \\
\hline Oc-OH-Tam & $-2 \mathrm{e}^{-} /-1 \mathrm{H}^{\mathrm{b}}$ & 331 & QM & $0.305 \pm 0.002^{d}$ \\
\hline OH-Tam[3] & $-1 \mathrm{e}^{-/}-1 \mathrm{H}^{\mathrm{c}}$ & None & n.d. & $0.471 \pm 0.02^{\mathrm{e}}$ \\
\hline
\end{tabular}

\section{In vitro inhibition studies on TrxR1 and TrxR2}

The possible inhibitory activity of the three TLMs and the three organic analogues was first investigated on TrxR1 and TrxR2 purified from the rat liver. Experimentally, mixtures of pre-reduced TrxR1 or TrxR2 and various concentrations of each compound were incubated for 5 min before their enzymatic activity was measured. Table 2 lists the $\mathrm{IC}_{50}$ values deduced from these experiments.

Both Fc-OH-Tam and Oc-OH-Tam were moderate inhibitors of both TrxR1 and TrxR2, with $\mathrm{IC}_{50}$ values between 15 and $23 \mu \mathrm{M}$, while Rc-OH-Tam was slightly active on TrxR1 and inactive on TrxR2. In contrast, none of the organic counterparts was active on both TrxR1 and TrxR2. Strikingly different results were obtained when the TLMs were enzymatically oxidized by a mixture of $\mathrm{HRP}$ and $\mathrm{H}_{2} \mathrm{O}_{2}$ for 15 min prior to incubation with TrxR. Indeed, all three TLMs became potent inhibitors of TrxR1 with a remarkably low $\mathrm{IC}_{50}$ value of $60 \mathrm{nM}$ for the iron complex, followed by an $\mathrm{IC}_{50}$ value of $0.42 \mu \mathrm{M}$ for the ruthenium complex and $1.2 \mu \mathrm{M}$ for the osmium complex. It is also interesting to note that oxidized Fc-OH-Tam was significantly more active on TrxR1 than on TrxR2. Conversely, preliminary treatment of OH-Tam[2] and OH-Tam[3] by $\mathrm{HRP} / \mathrm{H}_{2} \mathrm{O}_{2}$ led to moderate inhibition of only TrxR1 ( $\mathrm{IC}_{50}$ of $c a .8 \mu \mathrm{M}$ ) while HRP-treated Tam remained inactive on both TrxRs.

Table 2 In vitro inhibitory effect of tamoxifen-like metallocifens and organic tamoxifen derivatives on cytosolic (TrxR1) and mitochondrial (TrxR2) thioredoxin reductases 


\begin{tabular}{|c|c|c|c|c|}
\hline \multirow[b]{2}{*}{ Compound } & \multicolumn{2}{|c|}{$\mathrm{IC}_{50}{ }^{\mathrm{a}}(\mu \mathrm{M})$} & \multicolumn{2}{|c|}{$\begin{array}{c}\mathrm{IC}_{50} \mathrm{~b}(\mu \mathrm{M}) \text { after treatment } \\
\text { with } \mathrm{H}_{2} \mathrm{O}_{2} / \mathrm{HRP}\end{array}$} \\
\hline & TrxR1 & TrxR2 & TrxR1 & TrxR2 \\
\hline Fc-OH-Tam & $15 \pm 2^{c}$ & $32 \pm 3$ & $0.06 \pm 0.02$ & $10.9 \pm 1.2$ \\
\hline Rc-OH-Tam & $62 \pm 2$ & 4100 & $0.42 \pm 0.08$ & $4.6 \pm 0.1$ \\
\hline Oc-OH-Tam & $40 \pm 3.5$ & $23 \pm 3$ & $1.2 \pm 0.1^{d}$ & $3.9 \pm 0.1$ \\
\hline Tam & $>100$ & $>100$ & $>10$ & $>10$ \\
\hline OH-Tam[2] & $>100$ & $>100$ & $8.7 \pm 1.1$ & $>10$ \\
\hline OH-Tam[3] & $>100$ & $>100$ & $8.1 \pm 0.8$ & $>10$ \\
\hline
\end{tabular}

${ }^{a}$ Compounds were incubated with TrxR1 or TrxR2 in the presence of NADPH. After 5 min, TrxR activity was estimated as described in the Experimental section. ${ }^{b}$ Compounds were incubated in $0.2 \mathrm{M} \mathrm{Tris}-\mathrm{HCl}$ buffer ( $\mathrm{pH} 8.1$ ) containing $1 \mathrm{mM}$ EDTA, with $22 \mathrm{nM} \mathrm{HRP}$ and $0.1 \mathrm{mM} \mathrm{H} \mathrm{O}_{2}$ for $15 \mathrm{~min}$ at $25^{\circ} \mathrm{C}$. The mixture was then incubated with TrxR1 or TrxR2 as indicated in footnote a. ${ }^{\mathrm{c}}$ Value from ref. 8. ${ }^{\mathrm{d}}$ Value from ref. 16.

\section{Metallocifen interaction with the selenocysteine residue of $\operatorname{TrxR}$}

The C-terminal redox active site of TrxR is formed by a Cys-Sec motif ( $\mathrm{Sec}=$ selenocysteine), which is the target of many electrophiles that inhibit TrxR by alkylation of Cys and/or Sec residues.

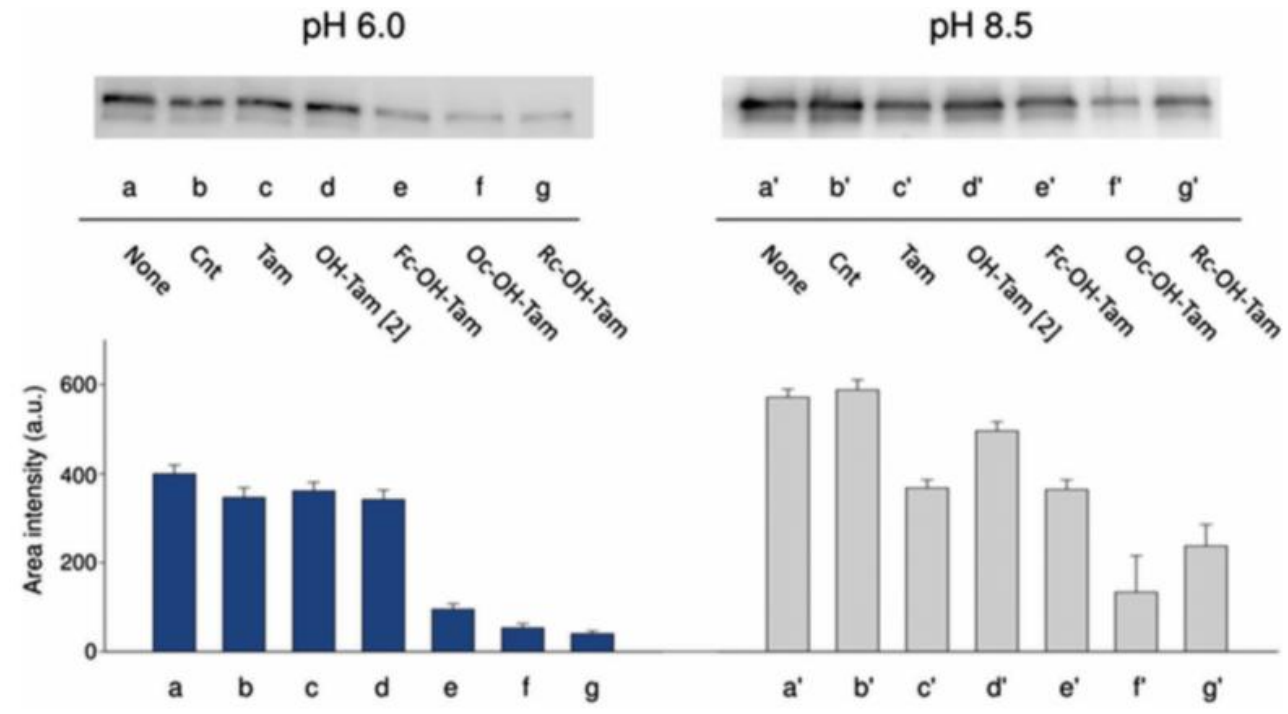

Fig. 1 BIAM assay of TrxR1 treated with compounds oxidized by $\mathrm{HRP} / \mathrm{H}_{2} \mathrm{O}_{2}$. TLMs and Tam derivatives $(2 \mu \mathrm{M})$ were treated with $\mathrm{HRP} / \mathrm{H}_{2} \mathrm{O}_{2}$ for $15 \mathrm{~min}$. The oxidized derivatives obtained (Ox-Mc with $\mathrm{Mc}=$ Fc, Oc, Rc; Ox-OH-Tam[2], Ox-Tam) were incubated in the presence of a pre-reduced aliquot of TrxR1, as reported in the Experimental section. Then, aliquots of the reaction mixture were added to $50 \mu \mathrm{M}$ biotinylated iodoacetamide (BIAM) in buffer at either $\mathrm{pH} 6.0$ (0.1 M Hepes-Tris) or $\mathrm{pH} 8.5(0.1 \mathrm{M}$ Tris- $\mathrm{HCl})$ to alkylate the $-\mathrm{SH} /-\mathrm{SeH}$ remaining groups. Proteins were transferred to a nitrocellulose membrane, and BIAM conjugated enzyme was detected with a streptavidin-horseradish peroxidase conjugate. a, a' : None; b, b': Cnt; c, c': Ox-Tam; d, d': Ox-OH-Tam[2]; e, e': Ox-Fc; f, f': Ox-Oc; g, g' : Ox-Rc. 
Discrimination between both residues can be achieved by carrying out the biotiniodoacetamide (BIAM) assay. As the $\mathrm{p} K \mathrm{a}$ values of both residues are different $(\mathrm{p} K \mathrm{a}$ R$\mathrm{SeH} / \mathrm{R}_{-} \mathrm{Se}^{-}=5.24 ; \mathrm{p} K \mathrm{a}$ R-SH/R-S ${ }^{-}=8$ ), selective alkylation by BIAM can be achieved according to the $\mathrm{pH}$. At low $\mathrm{pH}(6)$, only the selenolate group of Sec is alkylated by BIAM, while at high $\mathrm{pH}$ (8.5) both the thiolate and the selenolate groups of Cys and Sec are simultaneously alkylated by BIAM. ${ }^{32}$ Mixtures of TrxR1 and oxidized TLMs or organic tamoxifens were allowed to react with BIAM at $\mathrm{pH} 6$ or 8.5 to alkylate the remaining selenolate and/or thiolate groups and the samples were subjected to the Western blot analysis (Fig. 1). Very weak bands were observed for TrxR1 samples exposed to the oxidized TLMs and then to BIAM at pH 6 while the organic analogues had no effect. As a consequence, the three oxidized TLMs equally interacted with Sec by probable alkylation of the highly nucleophilic selenolate group. When alkylation by BIAM was carried out at $\mathrm{pH}$ 8.5, the TrxR1 sample exposed to Oc-OH-Tam gave a band weaker than the control, indicating that only oxidized Oc-OH-Tam was able to simultaneously alkylate the thiol groups. In addition, the $\mathrm{HRP} / \mathrm{H}_{2} \mathrm{O}_{2}$ mixture alone had no effect on the ability of BIAM to alkylate TrxR1 (cnt, lane b and b').

\section{Activities of cytosolic and mitochondrial thioredoxin reductases in Jurkat cells}

Jurkat cells $\left(2 \times 10^{6}\right)$ were incubated with each compound $(15 \mu \mathrm{M})$ for $18 \mathrm{~h}$. Then, the activity of total TrxR was determined in cell lysates (Fig. S2, ESI $†$ ). A large decrease of the total TrxR activity (60 to $95 \%$ inhibition) was observed in cells treated with the three TLMs while Tam and OH-Tam[2] induced a slight increase of activity and OH-Tam[3] had no effect. Additional experiments with Fc-OH-Tam showed that the activity of total TrxR was time-dependent as a slight increase was observed after $3 \mathrm{~h}$ followed by progressive and slow inhibition in the next $15 \mathrm{~h}$ (Fig. S3, ESI $\dagger$ ). After optimization of the ratio between compounds $(30 \mu \mathrm{M})$ and cell number $\left(3 \times 10^{7}\right)$, the activity of TrxR1 and TrxR2 was measured separately in the cytosolic and mitochondrial fractions of Jurkat cells (Fig. 2). High inhibition of TrxR2 was found for cells exposed to Fc-OH-Tam and Rc-OH-Tam $(72 \%$ and 79.4\% inhibition, respectively), while Oc-OH-Tam was less effective (44\% inhibition). However, organic tamoxifens were significantly less potent (up to $27 \%$ inhibition). In contrast, the effect of the three TLMs on TrxR1 was less pronounced (25-36\% inhibition) 
and not much different from that of the organic compounds (12-21\% inhibition).

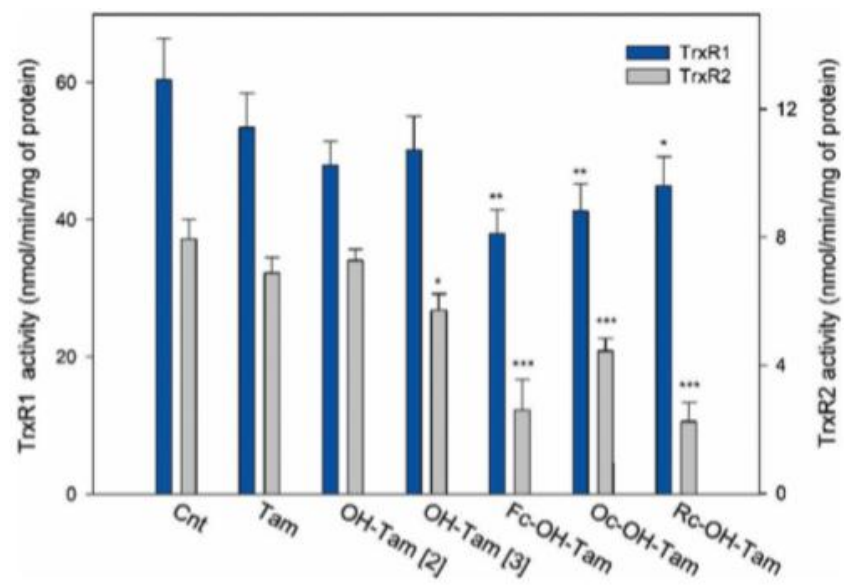

Fig. 2 TrxR1 and TrxR2 activities in Jurkat cells. Cytosolic and mitochondrial fractions were isolated from Jurkat cells treated with different compounds $\left(30 \mu \mathrm{M} / 3 \times 10^{7}\right.$ cells for $\left.18 \mathrm{~h}\right)$, and TrxR activities were estimated as reported in the Experimental section. *: $<0.05 ; * *:<0.01 ; * * *:<$ 0.001 .

\section{Mitochondrial thioredoxin (Trx2) redox state in Jurkat cells}

As all three TLMs and not the organic analogues induced strong inhibition of TrxR2 in Jurkat cells, the redox state of Trx 2 in cells exposed to each compound at $15 \mu \mathrm{M}$ for $18 \mathrm{~h}$ was evaluated by the protein electrophoretic mobility shift assay with iodoacetamide/iodoacetic acid (IAM/IAA) as follows. ${ }^{33}$ Lysates of cells incubated with each compound were first treated with IAM to titrate free $\mathrm{SH}$ groups, then, after reaction with DTT to reduce disulphide bonds, IAA was added in order to derivatize the SH groups arising from previously oxidized cysteines. The samples were submitted to urea-PAGE under non-reducing conditions and the 3 states of Trx 2 (fully oxidized, partially oxidized and fully reduced) were detected by Western blot analysis (Fig. 3).

Cells incubated with the 3 TLMs showed the accumulation of the fully oxidized form of Trx2, especially those exposed to Fc-OH-Tam (90\%) and to a lesser extent those exposed to Rc-OH-Tam and Oc-OH-Tam (57\%). Conversely, the fully reduced form of Trx2 was predominant in cells exposed to Tam and OH-Tam[2] (77\%). Only OHTam[3] induced the accumulation of a significant amount of oxidized forms of Trx2 ( $\mathrm{ca}$. $50 \%)$. 


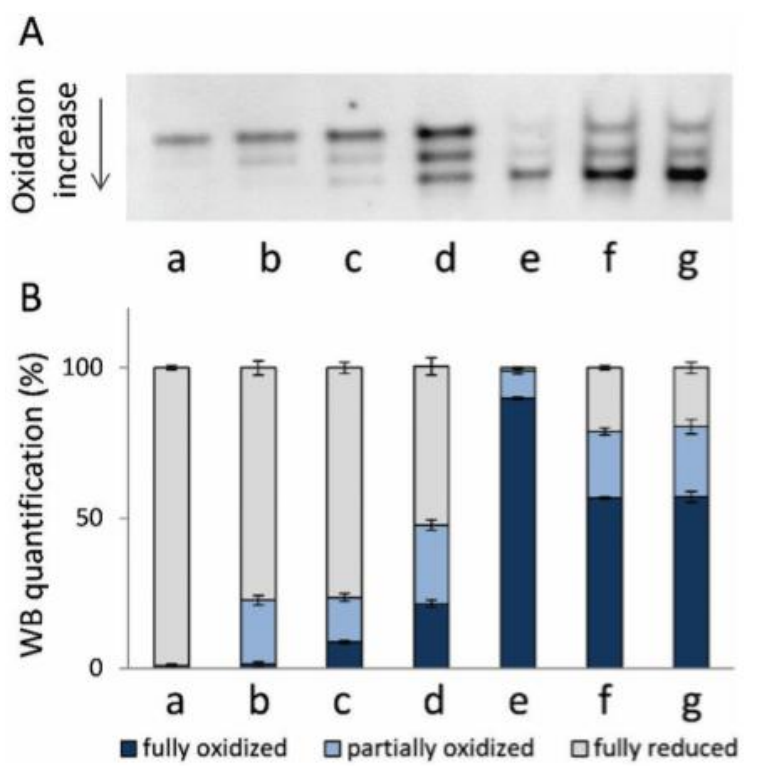

Fig. 3 Redox state of mitochondrial thioredoxin (Trx2) in Jurkat cells. Jurkat cells incubated for $18 \mathrm{~h}$ with $15 \mu \mathrm{M}$ TLMs or organic tamoxifens were lysed and the lysates were treated with a 10 mM IAM/IAA procedure to titrate reduced, partially oxidized and fully oxidized thiol groups. The redox state of Trx2 was then detected by Western blot analysis (A). (a) Cnt; (b) Tam; (c) OH-Tam[2]; (d) OH-Tam[3]; (e) Fc-OH-Tam; (f) Oc-OH-Tam; (g) Rc-OH-Tam. (B) Densitometric analysis of the lanes was performed using ImageJ software.

\section{ROS production and evaluation of the mitochondrial membrane potential (MMP) in Jurkat cells}

Short-term (0-30 min) mitochondrial ROS production in Jurkat cells was first measured using the DHR dye, after cell incubation with $10 \mu \mathrm{M}$ of the TLMs or organic tamoxifens. We found that the TLMs, but not the organic compounds, increased the basal ROS production during this period (Fig. S4, ESI $\dagger$ ). The long-term mitochondrial superoxide level was then evaluated in Jurkat cells incubated with $15 \mu \mathrm{M}$ TLMs or organic tamoxifens after $18 \mathrm{~h}$, by flow cytometry analysis using MitoSOX ${ }^{\mathrm{TM}}$ Red as a fluorescent probe (Fig. 4 left). A very high percentage of cells (72\%) incubated with Fc-OH-Tam emitted high MitoSOX ${ }^{\mathrm{TM}}$ fluorescence. This percentage was lower for cells incubated with Rc-OH-Tam and Oc-OH-Tam (around 40\%) while the percentage of cells emitting high MitoSOX fluorescence was insignificant for those incubated with the organic tamoxifens (6-8\%). The mitochondrial membrane potential (MMP) was evaluated on the same pool of cells by flow cytometry using the fluorescent dye TMRM (Fig. 4 right). The population of cells with a low MMP was close to $100 \%$ for cells incubated with the three TLMs for $18 \mathrm{~h}$ while the three organic tamoxifens affected the MMP to a much lower extent (up to $37.5 \%$ for $\mathbf{O H}$ - 
Tam[3]). Interestingly, the rate of depolarization of the mitochondrial membrane was fast for Fc-OH-Tam since the percentage of cells displaying a low MMP was already equal to $42 \%$ after 3 h (Fig. S5, ESI $\dagger$ ).

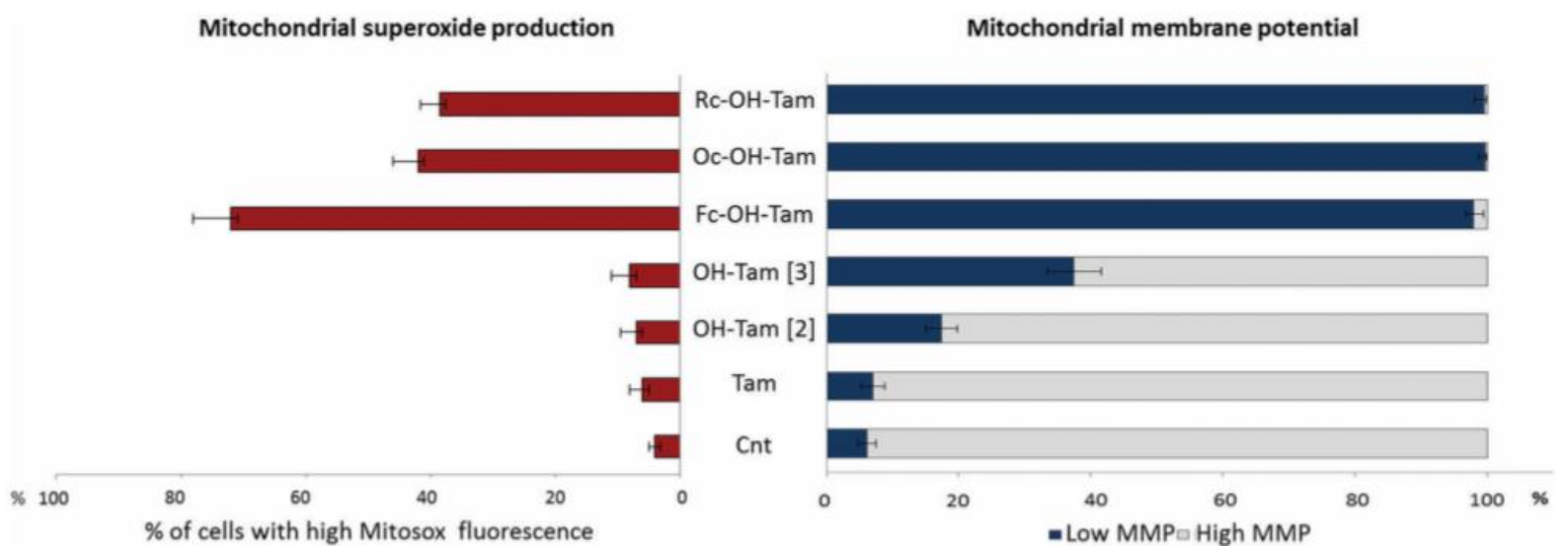

Fig. 4 Effects of TLMs and organic tamoxifens on mitochondrial superoxide production (left) and membrane potential (right) in Jurkat cells. Cells were treated for $18 \mathrm{~h}$ with various compounds (15 $\mu \mathrm{M})$. Then, aliquots of the cells were incubated in PBS/10 mM glucose in the presence of $1 \mu \mathrm{M}$ MitoSOX for the determination of superoxide production, or $25 \mathrm{nM}$ TMRM for the measurement of MMP. Fluorescence was detected using flow cytometric analysis. The left panel reports quantification of superoxide production (red bars). The right panel shows the MMP analysis in Jurkat cells where dark blue corresponds to the cell population with a low membrane potential, while light gray is related to the cell population with a high membrane potential.

\section{Activation of the apoptotic pathway}

The release of cytochrome $c$ and the state of caspase 3 were examined in Jurkat cells exposed to the three TLMs or the organic tamoxifens for $18 \mathrm{~h}$ (Fig. 5).

The results clearly show that after incubation with the three TLMs, cytochrome $c$ was released from the mitochondria to the cytosol, whereas it was still located in the mitochondria for the cells treated with organic tamoxifens. Moreover, pro-caspase 3 was only detected in the cells exposed to organic tamoxifens and not in the cells exposed to TLMs. Thus, only TLMs and not organic tamoxifens were able to trigger cell apoptosis by the mitochondria-mediated pathway. 


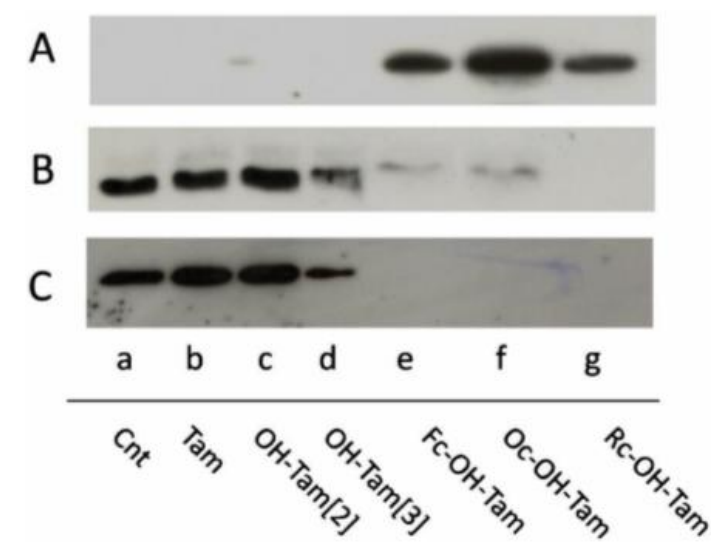

Fig. 5 Apoptosis pathway activation in Jurkat cells incubated with TLMs or tamoxifen derivatives. Jurkat cells $\left(2 \times 10^{6}\right)$ were treated for $18 \mathrm{~h}$ in the presence of $15 \mu \mathrm{M}$ compounds. Cytochrome $c$ localization was evaluated in the cytosol (A) and in the mitochondria (B); pro-caspase-3 detection is reported in (C). (a) Cnt; (b) Tam; (c) OHTam[2]; (d) OH Tam[3]; (e) Fc-OH-Tam; (f) Oc-OH-Tam; (g) Rc-OH-Tam.

\section{Intracellular distribution of metals in Jurkat cells}

As we found that metallocifens induced mitochondrial impairment we undertook, by ICPOES, quantification of iron, ruthenium and osmium in the mitochondria and cytosol of cells exposed to Fc-OH-Tam, Rc-OH-Tam and Oc-OH-Tam (Table 3 and Fig. S6, ESI $\uparrow$ ). As iron is a metal present in cells, its quantification was also performed in untreated cells.

Table 3 ICP-OES quantification of iron, ruthenium and osmium in the cytosol and mitochondria of Jurkat cells incubated for $24 \mathrm{~h}$ with $30 \mu \mathrm{M}$ Fc-OH-Tam, Oc-OH-Tam and Rc-OH-Tam, and of iron in untreated cells

\begin{tabular}{|c|c|c|}
\hline Compound & $\begin{array}{c}\text { Cytosol } \\
\text { (nmol mg }{ }^{-1} \text { protein) }\end{array}$ & $\begin{array}{c}\text { Mitochondria } \\
\text { (nmol mg } \\
\text { (nmotein) }\end{array}$ \\
\hline Fc-OH-Tam ${ }^{\mathrm{a}}$ & $10 \pm 5$ & $153 \pm 43$ \\
\hline Oc-OH-Tam & $5.5 \pm 4.9$ & $108 \pm 31$ \\
\hline Rc-OH-Tam ${ }^{c}$ & $0.13^{d}$ & 75 \\
\hline Untreated cells $(\mathrm{Fe})$ & $1.5 \pm 0.9$ & $19 \pm 11$ \\
\hline
\end{tabular}

The amounts of iron, osmium and ruthenium in the cytosol and in the mitochondria were in the same order of magnitude, indicating that the three TLMs were all able to 
accumulate in cells, with a high concentration in the mitochondria. The amount of iron in the cytosol and mitochondria of cells incubated with $30 \mu \mathrm{M}$ Fc-OH-Tam was significantly higher than the level of iron in the control cells, indicating that it mostly originated from Fc-OH-Tam and not from the endogenous iron pool.

The subcellular distribution of the metals gave an almost exclusive localization in the nuclear crude fractions (45-54\%) and mitochondria (37-50\%), and only a marginal localization in the cytosol (5-9\%) (Table 4).

Table 4 Subcellular distribution (\%) of Fe and Os in Jurkat cells incubated with $30 \mu \mathrm{M}$ Fc-OH-Tam and Oc-OH-Tam for $24 \mathrm{~h}$

\begin{tabular}{lccc}
\hline Compound & Cytosolic & Mitochondrial & Crude nuclear \\
& fraction (\%) & fraction (\%) & fraction (\%) \\
\hline Fc-OH-Tam $^{\text {a }}$ & $9 \pm 2$ & $37 \pm 7$ & $54 \pm 9$ \\
Oc-OH-Tam $^{\text {b }}$ & $5 \pm 2$ & $50 \pm 7$ & $45 \pm 4$ \\
a Mean of 3 experiments. $^{\text {b }}$ Mean of 2 experiments. &
\end{tabular}

Lipophilic cations are well known to preferentially localize in mitochondria. ${ }^{34,35}$ At physiological $\mathrm{pH}$, the dimethylamino group of TLMs is protonated, thus they can be considered as lipophilic cations. Consequently, they are expected to target mitochondria. Such behaviour is also encountered for other lipophilic metal-based drug candidates of gold(I), ${ }^{36}$ osmium(II), ${ }^{37}$ and rhenium(I) ${ }^{38}$

\section{Discussion}

In vitro inhibition of TrxR by TLMs occurred after their enzymatic oxidation by the $\mathrm{HRP} / \mathrm{H}_{2} \mathrm{O}_{2}$ mixture, and the products of oxidation were in general more active on the cytosolic isoform ( $\mathrm{IC}_{50}$ in the $0.06-1.2 \mu \mathrm{M}$ range) than on the mitochondrial form $\left(\mathrm{IC}_{50}\right.$ in the 3.9-10.9 $\mu \mathrm{M}$ range, Table 1). In contrast, oxidized organic tamoxifen derivatives were 
much poorer inhibitors of $\operatorname{TrxR}$, thus underlining the essential role played by the metallocenic entity in the oxidation profile and in the inactivation of TrxR. Independent spectroscopic studies showed that the species responsible for TrxR inhibition were their quinone methides for Fc-OH-Tam and Rc-OH-Tam and the quinone methide cation for OcOH-Tam, all of which displayed a highly electrophilic character. The inability of the $\mathrm{HRP} / \mathrm{H}_{2} \mathrm{O}_{2}$ system to generate the QM of organic tamoxifens confirmed this assertion. Within the TLM series, the extent of inhibition depends on both the metallocene unit and the TrxR isoform. Oxidized Fc-OH-Tam was significantly less efficient on TrxR2 than Rc-OHTam and Oc-OH-Tam while the reverse was observed for TrxR1 for which oxidized Fc-OHTam was the most active $\left(\mathrm{IC}_{50}=0.06 \mu \mathrm{M}\right)$. This very low value is in the range of those measured for gold(I) complexes which are recognized as very potent inhibitors of TrxR. ${ }^{14,39-41}$

The mechanism of inhibition of TrxR1 by the oxidized TLMs was investigated by the BIAM assay. This assay demonstrated that only the 3 oxidized TLMs and not the organic tamoxifens interacted with the C-terminal redox active site of TrxR1. Oxidized Fc-OH-Tam and Rc-OH-Tam selectively interacted with the penultimate selenocysteine residue while oxidized Oc-OH-Tam was also able to interact with the cysteine residues. The fact that the product of oxidation of Oc-OH-Tam is a quinone methide carbocation ${ }^{15}$ and not the neutral quinone methide may provide a rationale for this different reactivity.

Very different behaviour was observed in Jurkat cells, since the TLMs themselves were able to inhibit TrxR, indicating that their activation occurred in cellulo by endogenous oxidation systems. Moreover, all three TLMs were more efficient inhibitors of TrxR2 compared to TrxR1. This rather puzzling result is easily understandable when considering the subcellular distribution of the complexes, namely low concentrations in the cytosol and high concentrations in the mitochondria. Such an inversion of selectivity was previously noticed for cationic and lipophilic gold(I) complexes that displayed the same ability to preferentially accumulate in mitochondria. ${ }^{42}$ The fact that inhibition of the mitochondrial thioredoxin system was coupled with alteration of the MMP, overproduction of ROS and translocation of cytochrome $c$ may have to do with the recently reported deregulation of the redox state of cyclophilin $\mathrm{D}$, a mitochondrial enzyme involved in the regulation of the mitochondrial permeability transition process. ${ }^{43}$ In contrast, organic tamoxifens were far less potent TrxR inhibitors than metallocifens in cells. This finding is in line with the results on 
purified TrxR and highlights again the essential input of the metallocenic units on the biological activity of TLMs.

Among the three TLMs, Fc-OH-Tam behaved differently from the two others regarding the redox state of Trx2, as cells incubated with Fc-OH-Tam contained $90 \%$ of the fully oxidized form of Trx2, but those incubated with Rc-OH-Tam and Oc-OH-Tam contained only 57\%. Fc-OH-Tam also induced a higher level of mitochondrial superoxide and an early decrease in MMP.

These differences may be accountable to the much lower redox potential of ferrocene derivatives $\left(+0.4 \mathrm{~V}\right.$ for $\mathrm{Fc},{ }^{7}$ versus $+0.8 \mathrm{~V}$ for $\mathrm{Rc},{ }^{44}$ and $+0.6 \mathrm{~V}$ for $\mathrm{Oc},{ }^{15}$ in their analogous metallociphenols). Indeed, according to Kovacic, only the metallocenes with a redox potential between +0.4 and $-0.44 \mathrm{~V}$ display anticancer activity since this range of potential is favorable for in vivo electron transfer and redox cycling. ${ }^{45}$ In our series, only Fc-OH-Tam fulfils this requirement.

\section{Conclusion}

We showed that TLMs became strong inhibitors of both isoforms of TrxR after their enzymatic oxidation with $\mathrm{HRP} / \mathrm{H}_{2} \mathrm{O}_{2}$. All the oxidized TLMs were stronger inhibitors of the cytosolic isoform TrxR1 with Fc-OH-Tam showing a remarkably low $\mathrm{IC}_{50}$ value of 60 nM. In Jurkat cells, TLMs preferentially accumulated in the mitochondria as compared to the cytosol. Accordingly, they preferentially inhibited the mitochondrial isoform of TrxR and stimulated the oxidation of Trx2, leading to a cell redox imbalance.

The induced permeability of the mitochondrial membrane elicited the release of cytochrome $c$ and activation of the caspase pathway, leading to cell apoptosis. This type of death found in Jurkat cells differs from that previously found in adherent tumour MDA-MB231 cells, in which senescence was mainly observed. This study uncovers for the first time the powerful pro-apoptotic effects of TLMs, which appear to be responsible for their cytotoxicity in a lymphoblastoid cancer cell line and could be relevant for future clinical applications in the chemotherapy of resistant tumours. 


\section{Abbreviations}

BIAM Biotin iodoacetamide

DHR Dihydrorhodamine 123

Fc-OH-Tam 1-[4-[3-(Dimethylamino)propyloxy]phenyl]-1-(4-hydroxyphenyl)-2-ferrocenyl-1butene

HRP Horseradish peroxidase

ICP-OES Inductively coupled plasma optical emission spectroscopy

MMP Mitochondrial membrane potential

Oc-OH-Tam 1-[4-[3-(Dimethylamino)propyloxy]phenyl]-1-(4-hydroxyphenyl)-2-osmocenyl1-butene

Rc-OH-Tam 1-[4-[3-(Dimethylamino)propyloxy] phenyl]-1-(4-hydroxyphenyl)-2ruthenocenyl-1-butene

Tam Tamoxifen, 1-[4-[2-(Methylamino)ethoxy]phenyl]-1,2-diphenyl-1-but-1-en

OH-Tam[2] 4-Hydroxy-tamoxifen, (E/Z)-4-[1-[4-[2-(Methylamino) ethoxy]phenyl]-2-phenyl-1buten-1-yl]-phenol

OH-Tam[3] (E/Z)-4-[1-[4-[2-(Methylamino)propyl]phenyl]-2-phenyl-1-buten-1-yl]-phenol

RFU Relative fluorescence unit

TLMs Tamoxifen-like metallocifens

TMRM Tetramethyl rhodamine methyl ester

TNBC Triple negative breast cancer

TrxR Thioredoxin reductase

TrxR1 Cytosolic thioredoxin reductase 


\section{Acknowledgements}

The authors acknowledge COST Actions CM1105 and CM1106 for financial support and for allowing fruitful collaboration, and Dr Benoit Caron and Dr Benoit Villemant in-charge of the ALIPP6 platform at the University Pierre et Marie Curie Paris for assistance in the ICP-OES experiments.

\section{References}

1 N. Harbeck and M. Gnant, Breast Cancer, Lancet, 2017, 389, 1134-1150.

2 G. Jaouen, A. Vessieres and S. Top, Ferrocifen type anticancer drugs, Chem. Soc. Rev., $2015, \mathbf{4 4}, 8802-8817$.

3 S. Top, A. Vessières, G. Leclercq, J. Quivy, J. Tang, J. Vaissermann, M. Huché and G. Jaouen, Synthesis, biochemical properties and molecular modelling studies of organometallic specific estrogen receptor modulators (SERMs), the ferrocifens and hydroxyferrocifens: evidence for an antiproliferative effect of hydroxyferrocifens on both hormone-dependent and hormone-independent breast cancer cell lines, Chem. - Eur. J., 2003, 9, 5223-5236.

4 A. L. Laine, E. Adriaenssens, A. Vessières, G. Jaouen, C. Corbet, E. Desruelles, P. Pigeon, R. A. Toillon and C. Passirani, The in vivo performance of ferrocenyl tamoxifen lipid nanocapsules in xenografted triple negative breast cancer, Biomaterials, 2013, 34, 6949-6956.

5 Q. Michard, G. Jaouen, A. Vessières and B. A. Bernard, Evaluation of the cytotoxic properties of organometallic ferrocifens on melanocytes, primary and metastatic melanoma cells, J. Inorg. Biochem., 2008, 102, 1980-1985. 
6 A. Vessières, C. Corbet, J. M. Heldt, N. Lories, N. Jouy, I. Laios, G. Leclercq, G. Jaouen and R. A. Toillon, A ferrocenyl derivative of hydroxytamoxifen elicits an estrogen receptor-independent mechanism of action in breast cancer cell lines, J. Inorg. Biochem., 2010, 104, 503-511.

7 E. A. Hillard, A. Vessières, L. Thouin, G. Jaouen and C. Amatore, Ferrocene-mediated proton-coupled electron transfer in a series of ferrocifen-type breast cancer drug candidates., Angew. Chem., Int. Ed., 2006, 45, 285-290.

8 A. Citta, A. Folda, A. Bindoli, P. Pascal Pigeon, S. Top, A. Vessières, M. Salmain, G. Jaouen and M. P. Rigobello, Evidence for targeting thioredoxin reductases with ferrocenyl quinone methides. A possible molecular basis for the anti-proliferative effect of hydroxyferrocifens on cancer cells, J. Med. Chem., 2014, 57, 8849-8859.

9 W. Q. Cai, L. W. Zhang, Y. L. Song, B. L. Wang, B. X. Zhang, X. M. Cui, G. M. Hu, Y. P. Liu, J. C. Wu and J. G. Fang, Small molecule inhibitors of mammalian thioredoxin reductase, Free Radical Biol. Med., 2012, 52, 257-265.

10 V. Gandin and A. P. Fernandes, Metal- and Semimetal- Containing Inhibitors of Thioredoxin Reductase as Anti-cancer Agents, Molecules, 2015, 20, 12732-12756.

11 Y. Liu, Y. J. Li, S. H. Yu and G. S. Zhao, Recent Advances in the Development of Thioredoxin Reductase Inhibitors as Anticancer Agents, Curr. Drug Targets, 2012, 13, $1432-1444$.

12 F. Saccoccia, F. Angelucci, G. Boumis, D. Carotti, G. Desiato, A. E. Miele and A. Bellelli, Thioredoxin Reductase and its Inhibitors, Curr. Protein Pept. Sci., 2014, 15, 621646.

13 A. Bindoli and M. P. Rigobello, Principles in Redox Signaling: From Chemistry to Functional Significance, Antioxid. Redox Signaling, 2013, 18, 1557-1593.

14 A. Bindoli, M. P. Rigobello, G. Scutari, C. Gabbiani, A. Casini and L. Messori, Thioredoxin reductase: A target for gold compounds acting as potential anticancer drugs, Coord. Chem. Rev., 2009, 253, 1692-1707.

15 H. Z. S. Lee, O. Buriez, F. Chau, E. Labbé, R. Ganguly, C. Amatore, G. Jaouen, A. 
Vessières, W. K. Leong and S. Top, Synthesis, characterization, and biological properties of osmium-based tamoxifen derivatives. Comparison with their homologues in the iron and ruthenium series, Eur. J. Inorg. Chem., 2015, 4217-4225.

16 V. Scalcon, S. Top, H. Z. S. Lee, A. Citta, A. Folda, A. Bindoli, W. K. Leong, M. Salmain, A. Vessieres, G. Jaouen and M. P. Rigobello, Osmocenyl-tamoxifen derivatives target the thioredoxin system leading to a redox imbalance in Jurkat cells, $J$. Inorg. Biochem., 2016, 160, 296-304.

17 M. Luthman and A. Holmgren, Rat-liver thioredoxin and thioredoxin reductase purification and characterization, Biochemistry, 1982, 21, 6628-6633.

18 M. P. Rigobello and A. Bindoli, in Methods in Enzymology: Thiol Redox Transitions in Cell Signaling, Pt B: Cellular Localization and Signaling, ed. E. Cadenas and L. Packer, 2010, vol. 474, pp. 109-122.

19 O. H. Lowry, N. J. Rosebrough, A. L. Farr and R. J. Randall, Protein measurement with the folin phenol reagent, J. Biol. Chem., 1951, 193, 265-275.

20 J. G. Fang, J. Lu and A. Holmgren, Thioredoxin reductase is irreversibly modified by curcumin - A novel molecular mechanism for its anticancer activity, J. Biol. Chem., 2005, 280, 25284-25290.

21 S. Prast-Nielsen, M. Cebula, I. Pader and E. S. J. Arner, Noble metal targeting of thioredoxin reductase - covalent complexes with thioredoxin and thioredoxin-related protein of $14 \mathrm{kDa}$ triggered by cisplatin, Free Radical Biol. Med., 2010, 49, 1765-1778.

22 D. A. Clayton and G. S. Shadel, Isolation of mitochondria from cells and tissues, Cold Spring Harbor Protoc., 2014, DOI: 10.1101/pdbtop074542.

23 N. A. Bersani, J. R. Merwin, N. I. Lopez, G. D. Pearson and G. F. Merrill, Protein electrophoretic mobility shift assay to monitor redox state of thioredoxin in cells, Methods Enzymol., 2002, 347, 317-326.

24 J. Ungerstedt, Y. Du, H. Zhang, D. Nair and A. Holmgren, In vivo redox state of Human thioredoxin and redox shift by the histone deacetylase inhibitor suberoylanilide hydroxamic acid (SAHA), Free Radical Biol. Med., 2012, 53, 2002-2007. 
25 P. Pigeon, S. Top, A. Vessières, M. Huché, E. A. Hillard, E. Salomon and G. Jaouen, Selective estrogen receptor modulators (SERMs) in the Ruthenocene series. Synthesis and biological behavior, J. Med. Chem., 2005, 48, 2814-2821.

26 S. Top, I. Efremenko, M. N. Rager, A. Vessieres, P. Yaswen, G. Jaouen and R. H. Fish, Derivatives Reacting with $\mathrm{Cp}^{*} \mathrm{Rh}$ Complexes that involve eta(1)-N, eta(2)-N,O, eta(1)-O, and eta(6) Bonding Modes, Inorg. Chem., 2011, 50, 271-284.

27 P. Messina, E. Labbé, O. Buriez, E. A. Hillard, A. Vessières, D. Hamels, S. Top, G. Jaouen, Y. M. Frapart, D. Mansuy and C. Amatore, Deciphering the activation sequence of ferrociphenol anticancer drug candidates, Chem. - Eur. J., 2012, 18, 65816587.

28 P. W. Fan, F. Zhang and J. L. Bolton, 4-hydroxylated metabolites of the antiestrogens tamoxifen and toremifene are metabolized to unusually stable quinone methides., Chem. Res. Toxicol., 2000, 13, 45-52.

29 A. M. Davies, M. E. Malone, E. A. Martin, R. M. Jones, R. Jukes, C. K. Lim, L. L. Smith and I. N. H. White, Peroxidase activation of 4-hydroxytamoxifen to free radicals detected by EPR spectroscopy, Free RadicalBiol.Med., 1997, 22, 423-431.

30 M. I. Rybinskaya, A. Z. Kreindlin and S. S. Fadeeva, On the problem of stabilization of alpha-carbocationic centers in metallocene series - related interconversions of permethylated alpha-metallocenyl carbocations and metallocenium cation-radicals of the iron sub-group, J. Organomet. Chem., 1988, 358, 363-374.

31 M. I. Rybinskaya, A. Z. Kreindlin, Y. T. Struchkov and A. I. Yanovsky, On the problem of stabilization of alpha-metallocenyl carbocation - synthesis, properties and Crystal-structure of C5ME5OSC5ME4CH2 + BPH4-.CH2CL2, J. Organomet. Chem., 1989, 359, 233-243.

32 J. R. Kim, H. W. Yoon, K. S. Kwon, S. R. Lee and S. G. Rhee, Identification of proteins containing cysteine residues that are sensitive to oxidation by hydrogen peroxide at neutral pH, Anal. Biochem., 2000, 283, 214-221.

33 Y. T. Du, H. H. Zhang, X. Zhang, J. Lu and A. Holmgren, Thioredoxin 1 Is Inactivated 
Due to Oxidation Induced by Peroxiredoxin under Oxidative Stress and Reactivated by the Glutaredoxin System, J. Biol. Chem., 2013, 288, 32241-32247.

34 A. Folda, A. Citta, V. Scalcon, T. Cali, F. Zonta, G. Scutari, A. Bindoli and M. P. Rigobello, Mitochondrial Thioredoxin System as a Modulator of Cyclophilin D Redox State, Sci. Rep., 2016, 6, 23071, DOI: 23010.21038/srep23071.

35 M. C. Frantz and P. Wipf, Mitochondria as a Target in Treatment, Environ. Mol. Mutagen., 2010, 51, 462-475.

36 L. Oehninger, R. Rubbiani and I. Ott, N-Heterocyclic carbene metal complexes in medicinal chemistry, Dalton Trans., 2013, 42, 3269-3284.

37 S. H. van Rijt, I. Romero-Canelon, Y. Fu, S. D. Shnyder and P. J. Sadler, Potent organometallic osmium compounds induce mitochondria-mediated apoptosis and S-phase cell cycle arrest in A549 non-small cell lung cancer cells, Metallomics, 2014, 6, 1014 1022.

38 S. Imstepf, V. Pierroz, R. Rubbiani, M. Felber, T. Fox, G. Gasser and R. Alberto, Organometallic Rhenium Complexes Divert Doxorubicin to the Mitochondria, Angew. Chem., Int.Ed., 2016, 55, 2792-2795.

39 A. Citta, E. Schuh, F. Mohr, A. Folda, M. L. Massimino, A. Bindoli, A. Casini and M. P. Rigobello, Fluorescent silver(I) and gold(I)-N-heterocyclic carbene complexes with cytotoxic properties: mechanistic insights, Metallomics, 2013, 5, 1006-1015.

40 O. Rackham, S. J. Nichols, P. J. Leedman, S. J. Berners-Price and A. Filipovska, A gold(I) phosphine complex selectively induces apoptosis in breast cancer cells: Implications for anticancer therapeutics targeted to mitochondria, Biochem. Pharmacol., 2007, 74, 992-1002.

41 E. Schuh, C. Pfluger, A. Citta, A. Folda, M. P. Rigobello, A. Bindoli, A. Casini and F. Mohr, Gold(I) Carbene Complexes Causing Thioredoxin 1 and Thioredoxin 2 Oxidation as Potential Anticancer Agents, J. Med. Chem., 2012, 55, 5518-5528.

42 O. Rackham, A. M. J. Shearwood, R. Thyer, E. McNamara, S. M. K. Davies, B. A. Callus, A. Miranda-Vizuete, S. J. Berners-Price, Q. Cheng, E. S. J. Arner and A. 
Filipovska, Substrate and inhibitor specificities differ between human cytosolic and mitochondrial thioredoxin reductases: Implications for development of specific inhibitors, Free Radical Biol. Med., 2011, 50, 689-699.

43 A. P. Halestrap and A. P. Richardson, The mitochondrial permeability transition: A current perspective on its identity and role in ischaemia/reperfusion injury, J. Mol. Cell. Cardiol., 2015, 78, 129-141.

44 H. Z. S. Lee, O. Buriez, E. Labbé, S. Top, P. Pigeon, G. Jaouen, C. Amatore and W. K. Leong, Oxidative Sequence of a Ruthenocene-Based Anticancer Drug Candidate in a Basic Environment, Organometallics, 2014, 33, 4940-4946.

45 P. Kovacic, Unifying mechanism for anticancer agents involving electron transfer and oxidative stress: Clinical implications, Med. Hypotheses, 2007, 69, 510-516. 


\section{Electronic supplementary information}

\section{Table of contents}

Fig. S1. UV-Vis spectra of enzymatic oxidation of Fc-OH-Tam, Rc-OH-Tam or OH$\operatorname{Tam}[3]$

Fig. S2. Total TrxR activity in Jurkat cell lysates

Fig. S3. Time scale of of total TrxR activity in cell lysates after treatment with Fc-OH-Tam

Fig. S4. Short-term ROS production of Jurkat cells after treatment with TLMs or organic tamoxifen derivatives

Fig. S5. Mitochondrial membrane potential (MMP) analysis of Jurkat cells after treatment with the various compounds at different times

Fig.S6. Calibration curves for Ru, Fe, Os measured by ICP-OES 
A

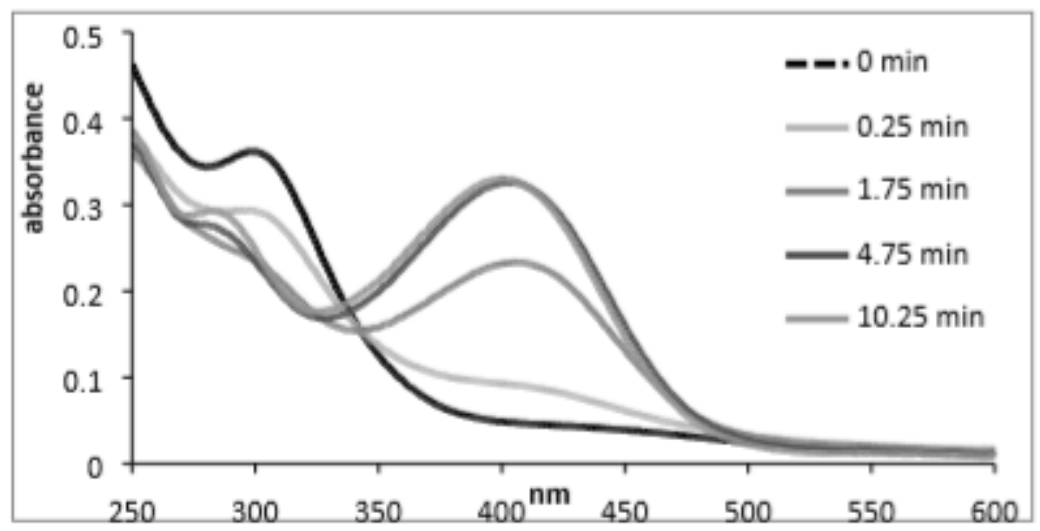

B

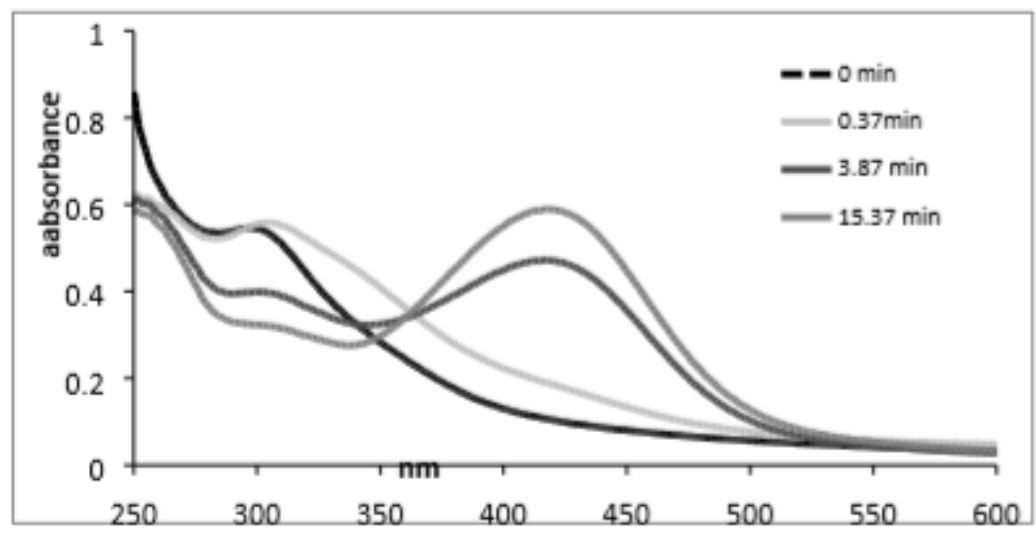

C

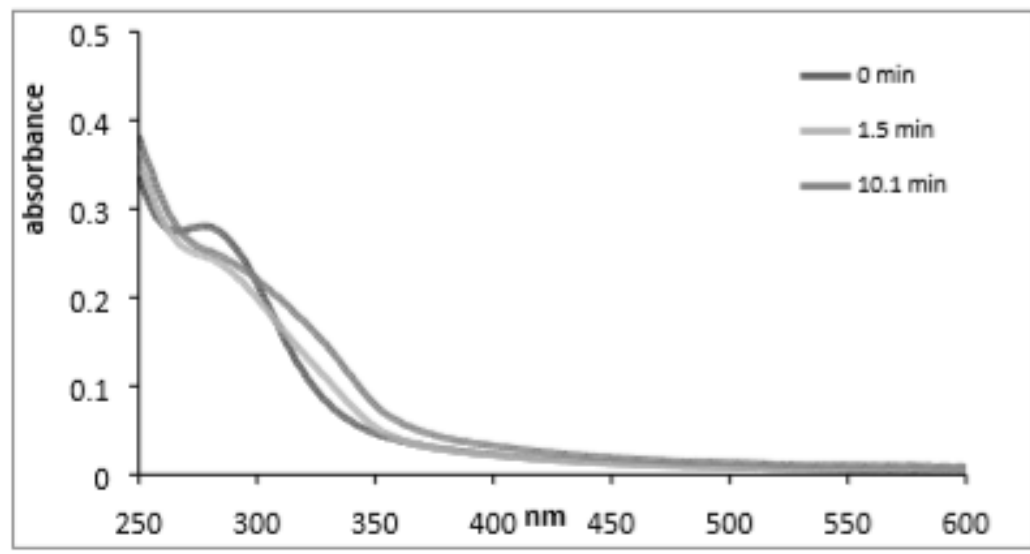

Fig.S1. UV-Vis spectral monitoring of enzymatic oxidation of Fc-OH-Tam (A), Rc-OHTam (B), or OHTam[3] (C). Each compound was mixed with HRP (44 nM) and $\mathrm{H}_{2} \mathrm{O}_{2}$ (200 $\mu \mathrm{M}$ ) in $0.2 \mathrm{M}$ Tris- $\mathrm{HCl}, 1 \mathrm{mM}$ EDTA $\mathrm{pH} 8.1$ and the UV-Vis spectra were recorded at the indicated times. Gradual appearance of a peak at $402 \mathrm{~nm}$ in the Fc-OH-Tam spectra (A) and a peak at $418 \mathrm{~nm}$ in the Rc-OH-Tam spectra (B) are assigned to the formation of the quinone methide derivatives. Disappearance of the peak at $279 \mathrm{~nm}$ for OHTam[3] (C) is assigned to its progressive oxidation without conversion to the quinone methide. (see Experimental Section for details) 


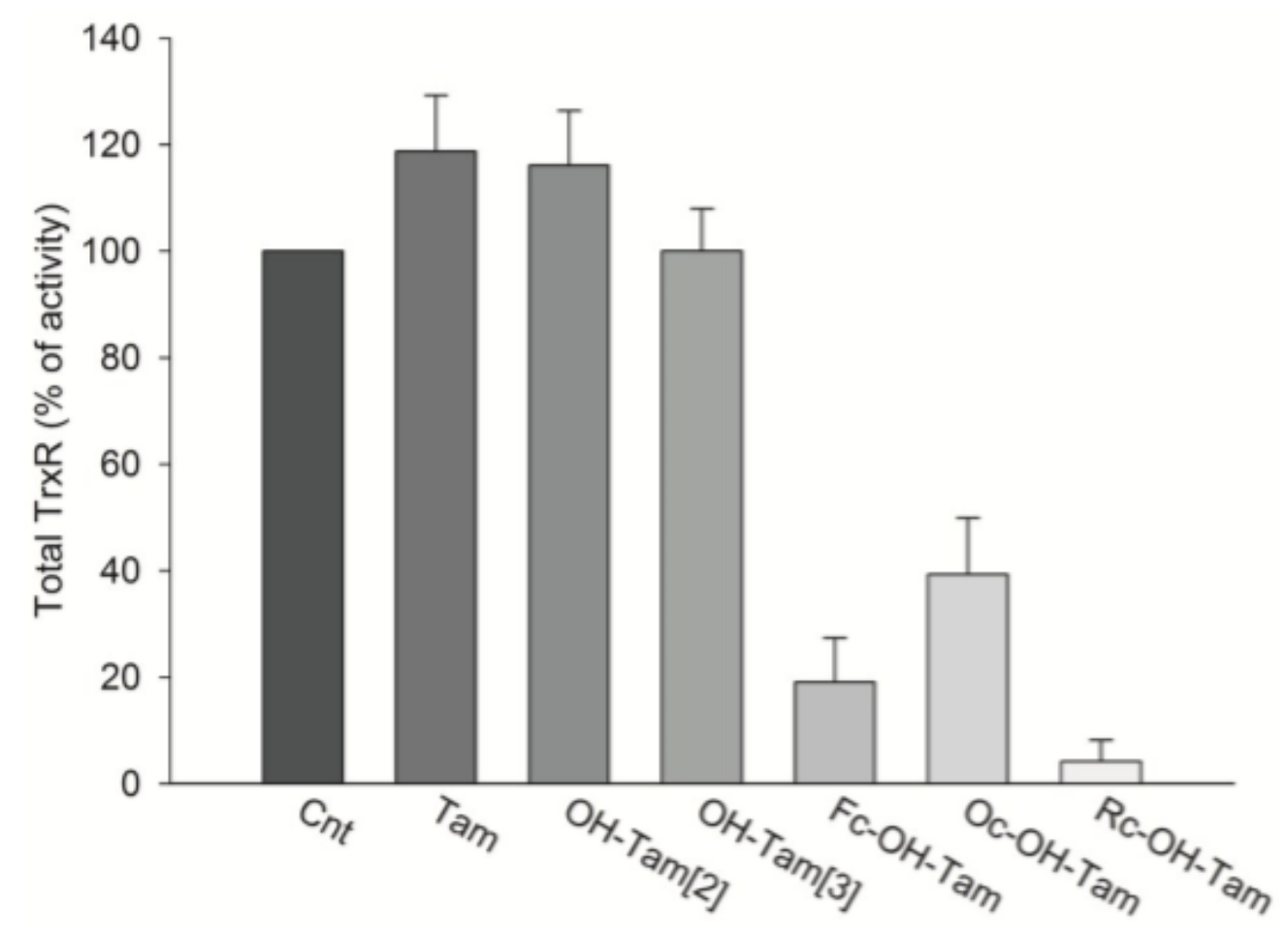

Fig. S2. Total TrxR activity in cell lysates. TrxR activity was determined after treatment of Jurkat cells $\left(2 \times 10^{6}\right)$ for $18 \mathrm{~h}$ with the indicated compounds $(15 \mu \mathrm{M})$ following the procedure reported in the Experimental Section.

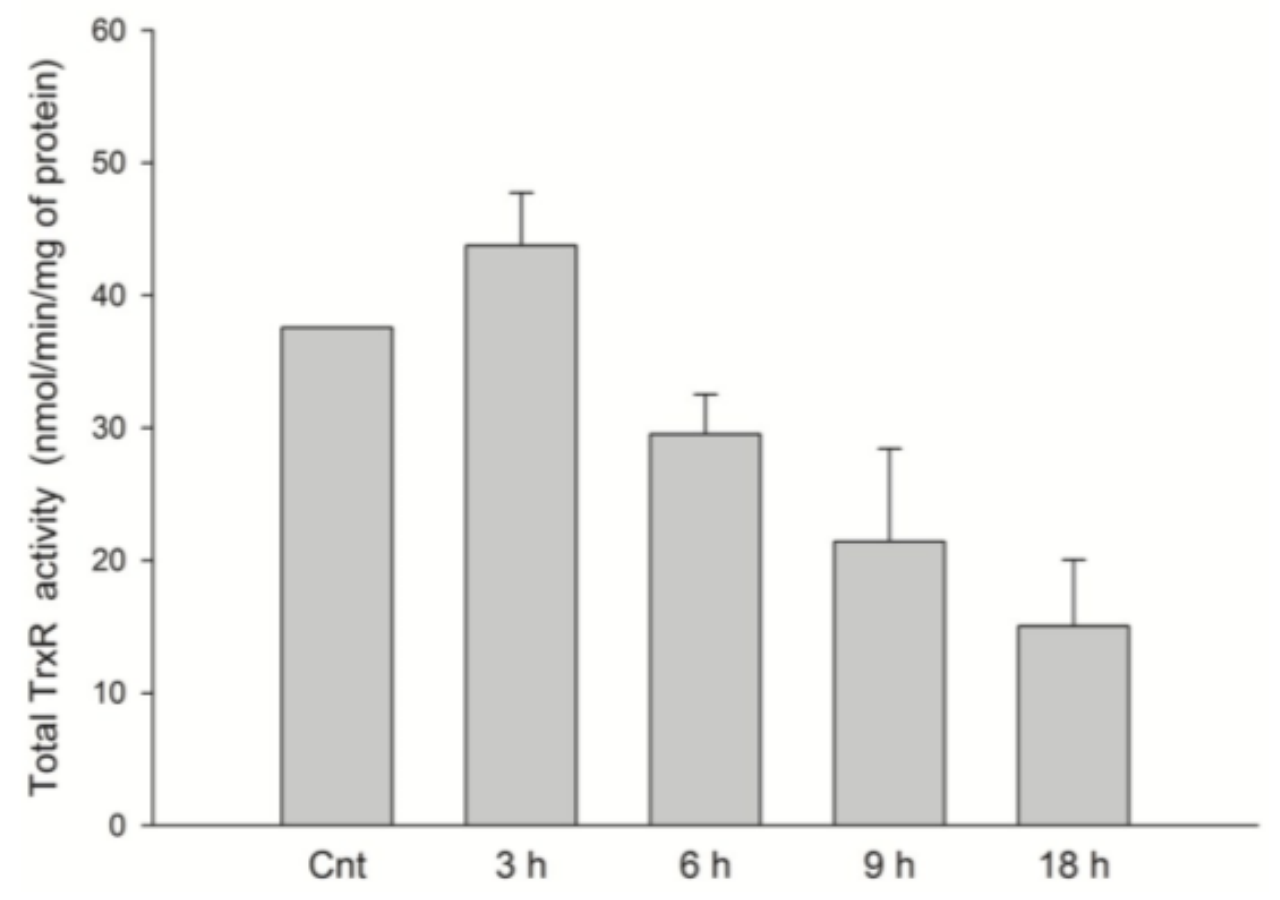

Fig. S3. Time scale of total TrxR activity in cell lysates after Fc-OH-Tam treatment. Jurkat cells $\left(2 \times 10^{6}\right)$ were treated for 3, 6, 9 or $18 \mathrm{~h}$ with $15 \mu \mathrm{M}$ Fc-OH-Tam, then lysed and subjected to thioredoxin activity assay as described in Experimental Section. 


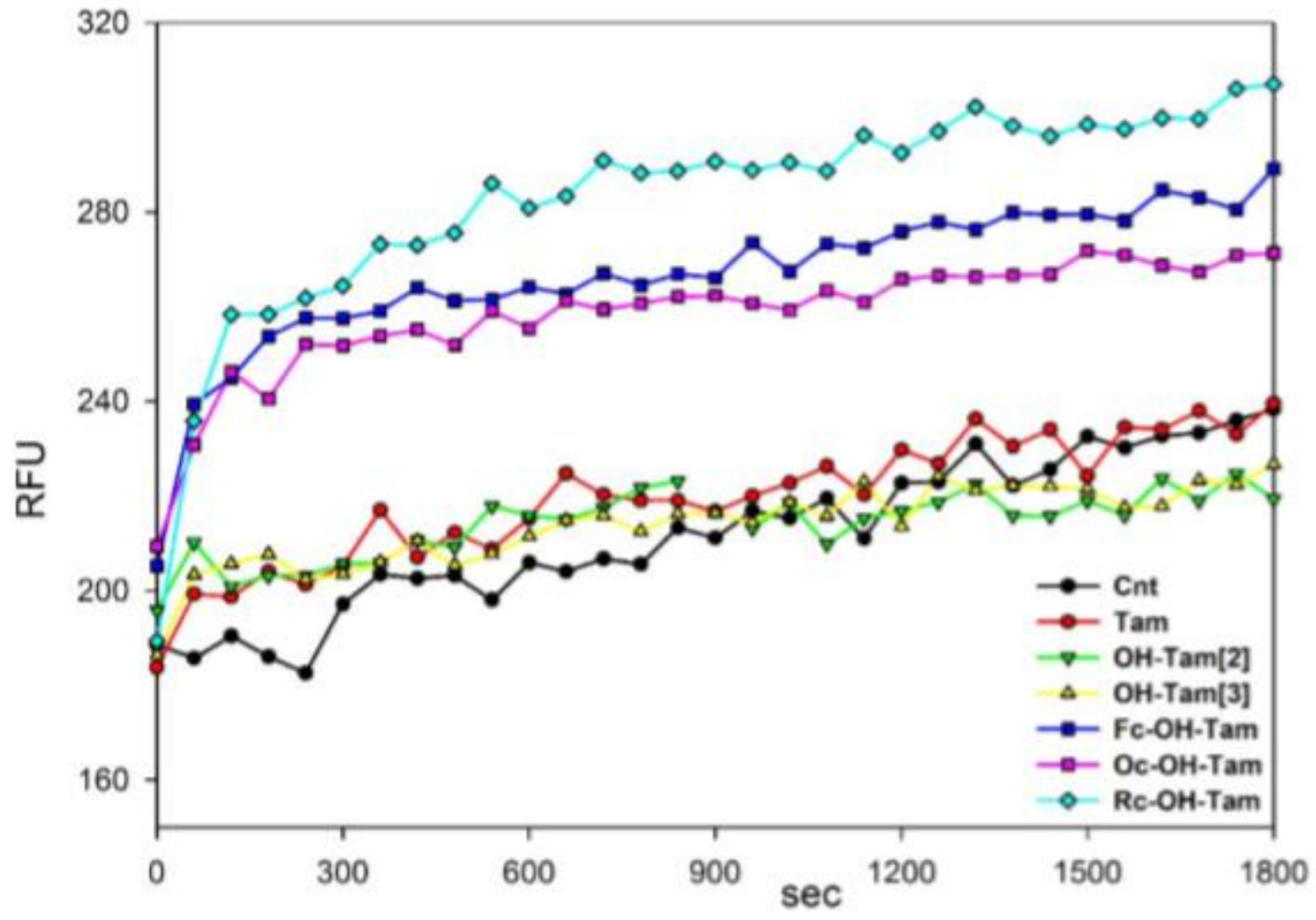

Fig. S4. Short-term ROS production of Jurkat cells after treatment with TLMs or organic tamoxifen derivatives. Jurkat cells ( $4 \times 10^{5} /$ well) were incubated for $1 \mathrm{~h}$ with $15 \mu \mathrm{M}$ DHR. Afterwards, the medium was removed and $10 \mu \mathrm{M}$ compounds were added to the cells. Fluorescence increase was monitored on a plate reader as reported in Experimental Section. 
A
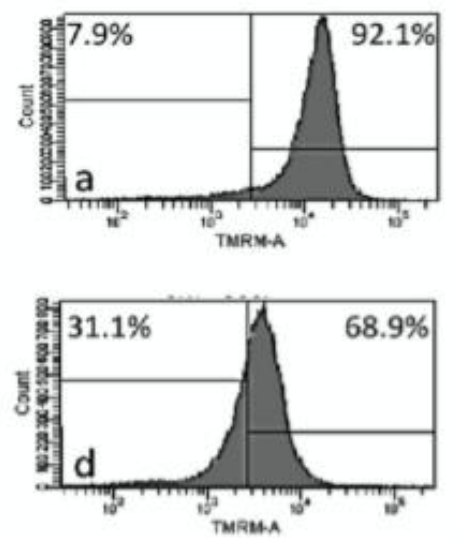

B
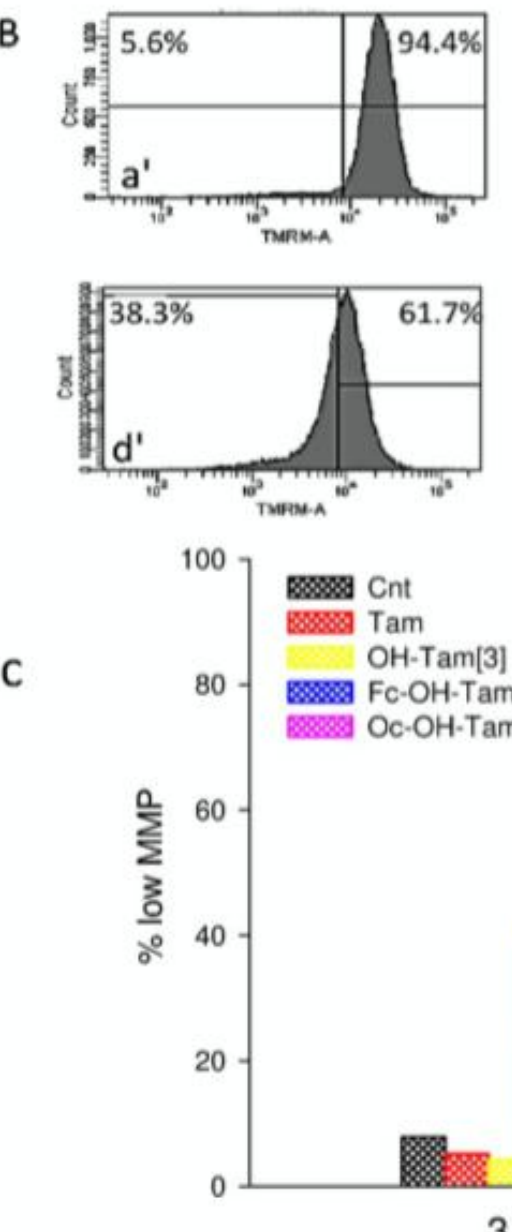
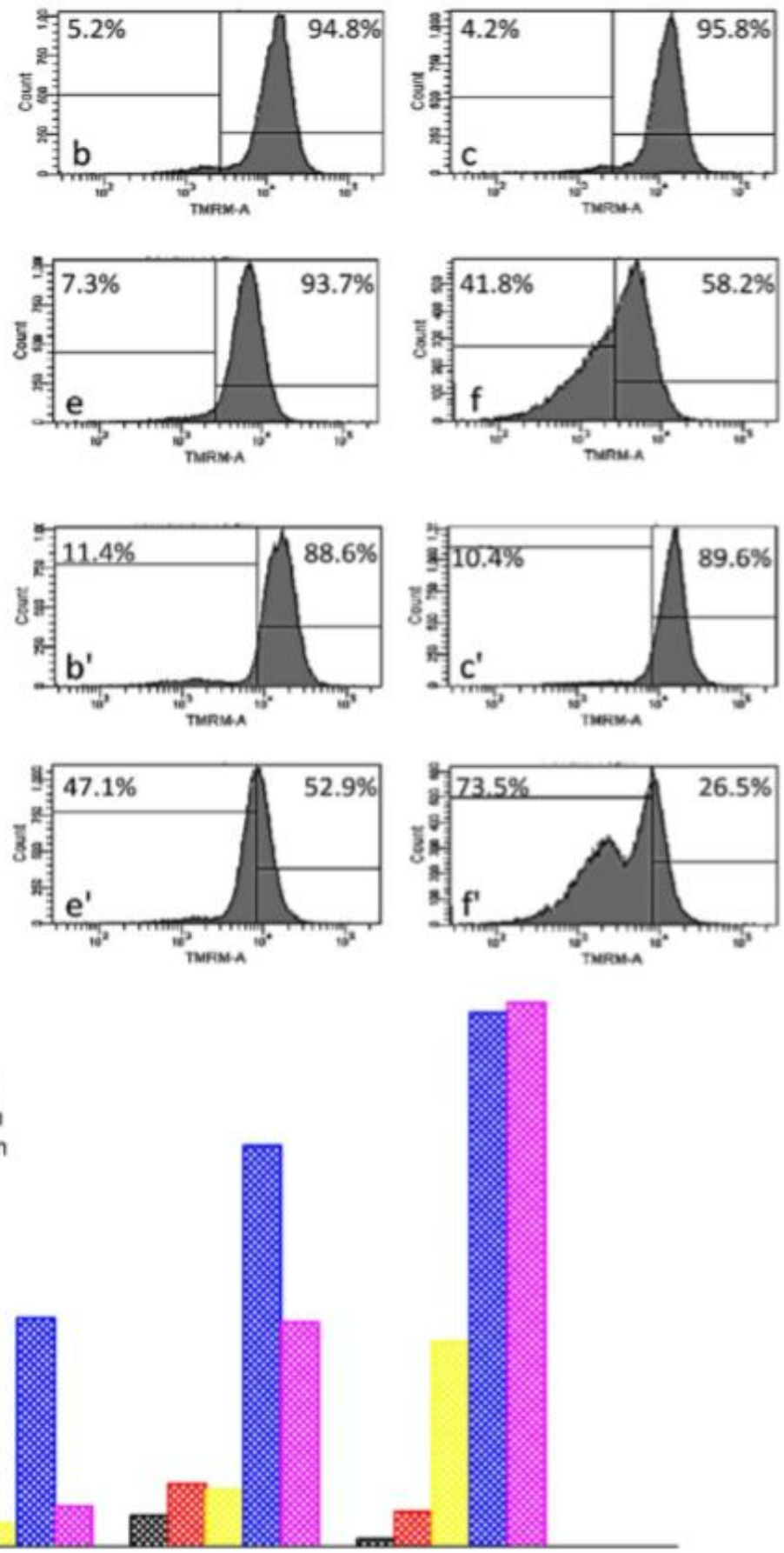

$18 \mathrm{~h}$

Fig. S5. Mitochondrial membrane potential (MMP) analysis of Jurkat cells after treatment with the various compounds at different incubation times. Cells $\left(1 \mathrm{x} 10^{6}\right)$ were treated for $3 \mathrm{~h}(\mathbf{A})$ or $6 \mathrm{~h}(\mathbf{B})$ with the indicated compounds $(15 \mu \mathrm{M})$ and MMP was measured on $3 \times 10^{4}$ cells by flow cytometry analysis following TMRM fluorescence intensity (see Experimental Section). The two populations divided by the vertical gate correspond to cells with low MMP (left) and cells with high MMP (right). $1 \mu \mathrm{M}$ carbonyl cyanide-mchlorophenylhydrazone (CCCP), a classic uncoupling agent, was used as a positive control. a,a' Cnt; b,b' Tam; c,c' OH-Tam[3]; d,d' CCCP; e,e' Oc-OH-Tam; f,f' Fc-OH-Tam. (C) Percentage of Jurkat cells with low MMP in the range 3-18 h from the treatment with $15 \mu \mathrm{M}$ compounds. 


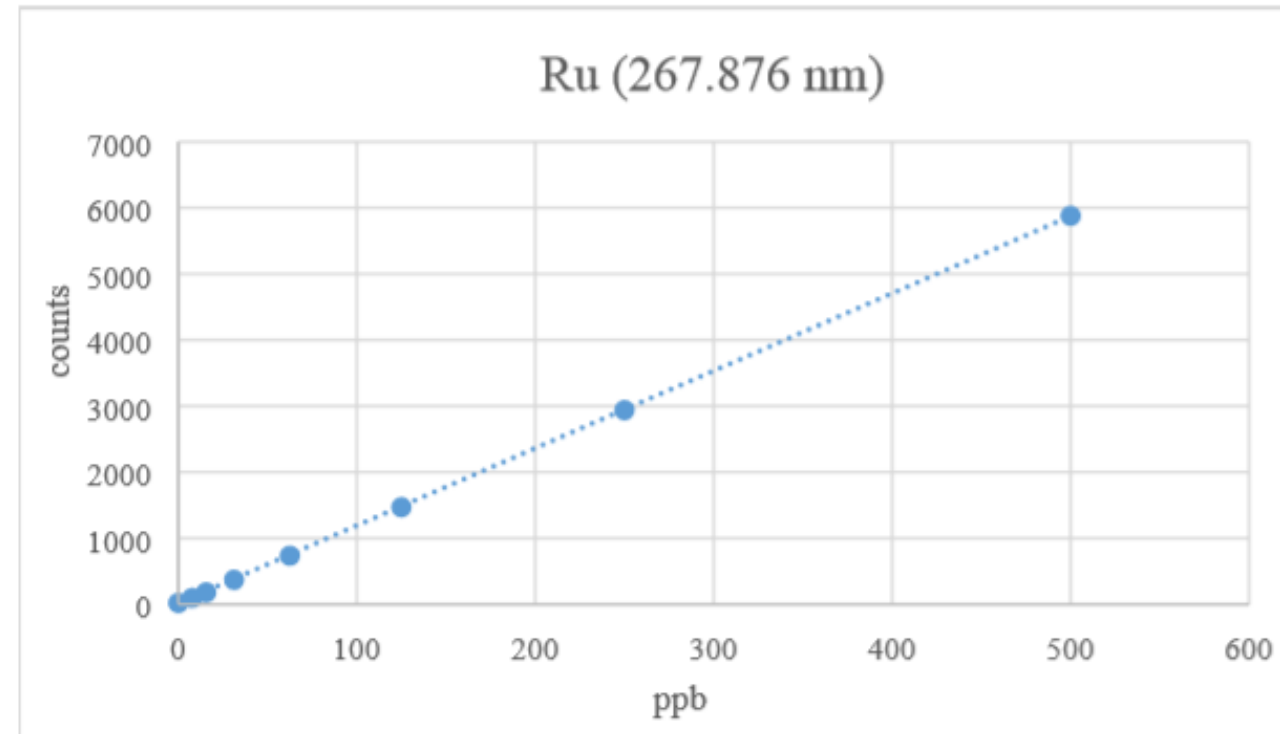

$\mathrm{Fe}(238.04 \mathrm{~nm})$

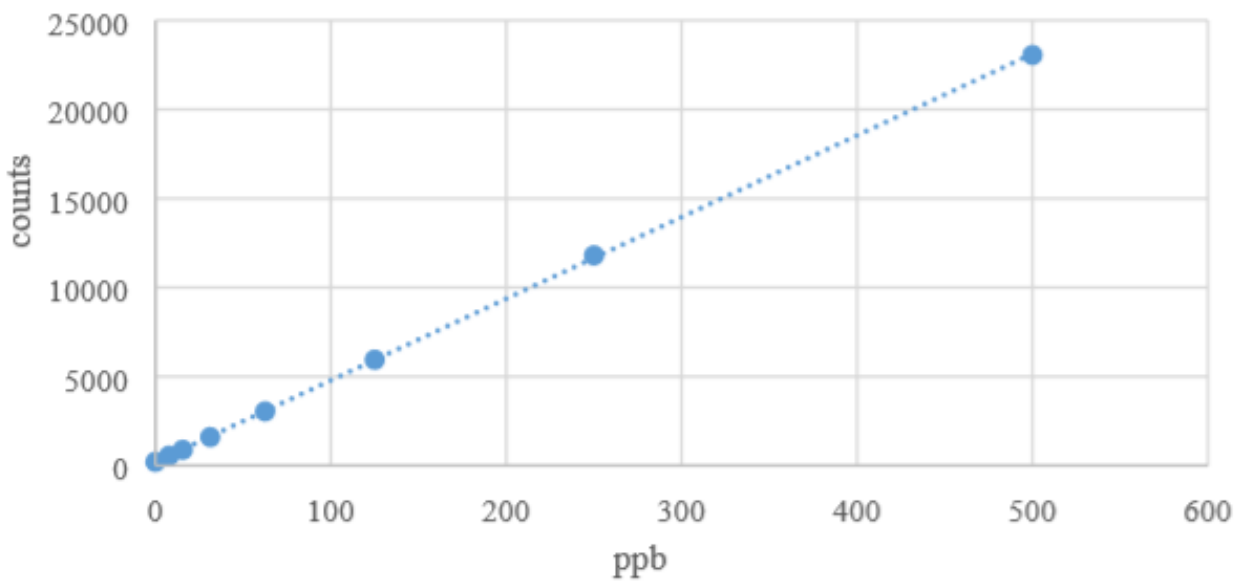

Os $(225.585 \mathrm{~nm})$

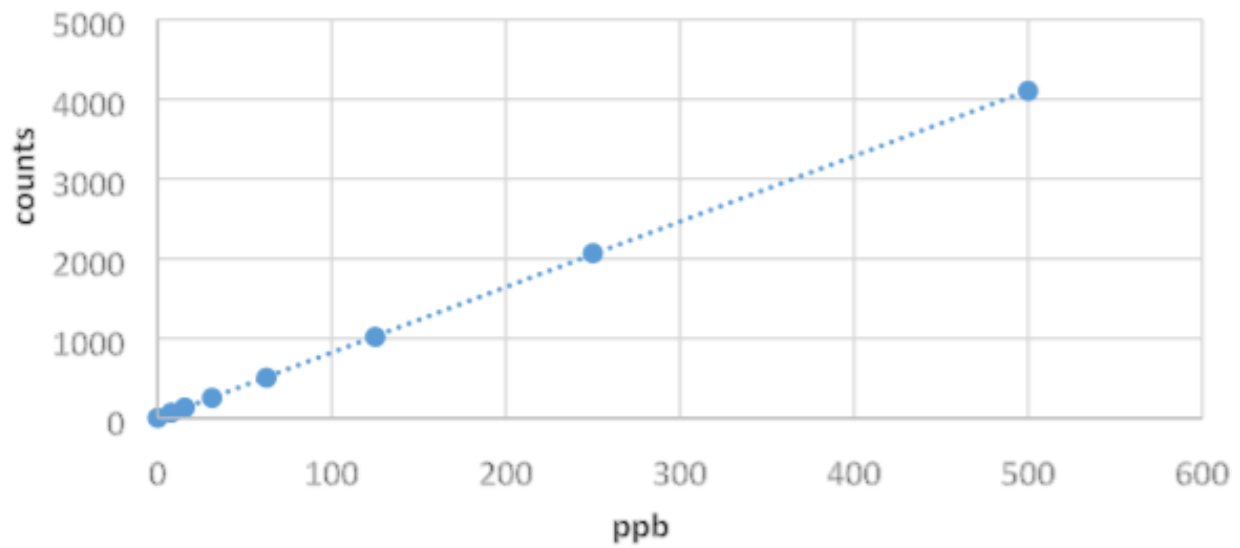

Fig. S6. Calibration curves for $\mathrm{Ru}, \mathrm{Fe}, \mathrm{Os}$ in the range $(7.8-500 \mathrm{ppb})$ measured by ICPOES 